\title{
Financial Integration, Financial Development, and Global Imbalances
}

Enrique G. Mendoza

University of Maryland and National Bureau of Economic Research

Vincenzo Quadrini

University of Southern California, Centre for Economic Policy Research, and National Bureau of Economic Research

\section{José-Víctor Ríos-Rull}

University of Minnesota, Federal Reserve Bank of Minneapolis, Centro de Análysis y Estudios Ríos Pérez, Centre for Economic Policy Research, and National Bureau of Economic Research

Global financial imbalances can result from financial integration when countries differ in financial markets development. Countries with more advanced financial markets accumulate foreign liabilities in a gradual, long-lasting process. Differences in financial development also affect the composition of foreign portfolios: countries with negative net foreign asset positions maintain positive net holdings of nondiversifiable equity and foreign direct investment. Three observations motivate our analysis: (1) financial development varies widely even among industrial countries, with the United States on top; (2) the secular decline in the U.S. net foreign asset position started in the early 1980s, together with a gradual process of international financial

We would like to thank Manuel Amador, David Backus, Luca Dedola, Linda Goldberg, Pierre-Olivier Gourinchas, Gita Gopinath, Ayse İmrohoroğlu, Patrick Kehoe, Kyungsoo Kim, and Alessandro Rebucci for insightful comments and Gian Maria Milesi-Ferretti and Philip Lane for sharing their cross-country data on foreign asset positions. We also thank participants at several universities and conferences. Financial support from the National Science Foundation is gratefully acknowledged: Quadrini with grant SES-0617937 and Ríos-Rull with grant SES-0079504. The views expressed herein are those of the authors and not necessarily those of the Federal Reserve Bank of Minneapolis or the Federal Reserve System.

[Journal of Political Economy, 2009, vol. 117, no. 3]

(C) 2009 by The University of Chicago. All rights reserved. 0022-3808/2009/11703-0001\$10.00 
integration; (3) the portfolio composition of U.S. net foreign assets features increased holdings of risky assets and a large increase in debt.

\section{Introduction}

At the end of 2006, the current account deficit of the United States reached 1.6 percent of the world's GDP, the largest in the country's history. Continuing a trend that started in the early 1980s, the U.S. net foreign asset (NFA) position fell to -5 percent of the world's output. During this period, the U.S. foreign asset portfolio also changed dramatically: net equity and foreign direct investment (FDI) climbed to one-tenth of U.S. GDP, whereas net debt obligations increased sharply to about one-third of U.S. GDP.

These unprecedented global imbalances are the focus of a large and growing literature. Some studies argue that the imbalances resulted from economic policy misalignments in the United States and abroad, ${ }^{1}$ whereas others argue that they were caused by events such as differences in productivity growth, business cycle volatility, demographic dynamics, a "global savings glut," or valuation effects. ${ }^{2}$ To date, however, a quantitatively consistent explanation of both the unprecedented magnitude of the changes in NFA positions and the striking changes in their portfolio structure has proven elusive.

In this paper we show that both of these phenomena can be explained as the equilibrium outcome of financial integration across countries with heterogeneous domestic financial markets. This is a relevant hypothesis because the reforms that integrated world capital markets starting in the 1980s were predicated on their benefits for efficient resource allocation and risk sharing across countries, ignoring the fact that domestic financial systems differed substantially, and these differences persist today despite the globalization of capital markets. In short, financial integration was a global phenomenon, but financial development was not.

The empirical motivation for our analysis derives from three key observations.

1. There is a high degree of heterogeneity in domestic financial markets across countries, and these differences remain largely unaltered despite financial glob-

\footnotetext{
${ }^{1}$ See, e.g., Obstfeld and Rogoff (2004), Summers (2004), Blanchard, Giavazzi, and Sa (2005), Roubini and Setser (2005), and Krugman (2006).

${ }^{2}$ See Backus et al. (2005), Bernanke (2005), Croke, Kamin, and Leduc (2005), Hausmann and Sturzenegger (2005), Henriksen (2005), Attanasio, Kitao, and Violante (2006), Cavallo and Tille (2006), Engel and Rogers (2006), Fogli and Perri (2006), Chakraborty and Deckle (2007), Deckle, Eaton, and Kortum (2007), Ghironi, Lee, and Rebucci (2007), Gourinchas and Rey (2007), Lane and Milesi-Ferretti (2007), Prades and Rabitsch (2007), Caballero, Farhi, and Gourinchas (2008), and McGrattan and Prescott (2008).
} 
alization and financial development. Figure $1 \mathrm{~A}$ plots the financial development index constructed by the International Monetary Fund for industrial countries (see IMF 2006). The index shows that there are large differences even among advanced economies, with the United States ranked first. In addition, the gaps of other industrial countries relative to the United States did not change significantly between 1995 and 2004. Similar features are evident in another index of financial development constructed by Abiad, Detragiache, and Tressel (2008) for industrial and emerging economies for the 1973-2002 period. As shown in figure $1 B$, while financial liberalization progressed in both OECD and emerging economies over the last 30 years, the gap between the two groups of countries has not changed.

2. The secular decline of the NFA position of the most financially developed country - the United States - began roughly at the same time as the financial globalization process, in the early 1980s. Figure $2 A$ shows the Chinn-Ito financial openness index for the United States, the industrial countries excluding the United States, and all countries except the United States. Capital markets in the United States have been relatively open to the rest of the world throughout the last three decades. Most of the other countries started opening their capital accounts gradually since the early 1980 s. Figure $2 B$ shows that this process of financial integration produced a worldwide surge in gross stocks of foreign assets and liabilities.

3. The decline in the U.S. NFA position was accompanied by a marked change in the portfolio composition of foreign assets of all countries. Figure 3 plots the two broad components of the total NFA positions: net debt instruments (including international reserves) and net portfolio equity and FDI. The plots show that the United States increased net holdings of risky assets (portfolio equity and FDI) and reduced net holdings of riskless assets into a very large negative position. Other industrial countries changed net holdings of risky assets in a similar way but hardly changed holdings of riskless assets. The emerging economies reduced net holdings of risky assets and increased holdings of riskless assets. See also Gourinchas and Rey (2007), Lane and Milesi-Ferretti (2007), and Curcuru, Dvorak, and Warnock (2008).

We build a model suitable for empirical analysis in which we take as given observations 1 and 2 to explain the facts highlighted in observation 3 (i.e., the changes in NFA positions and in their portfolio structure). In our model, countries are inhabited by ex ante identical agents who face two types of idiosyncratic shocks: endowment and investment shocks. Financial development is defined by the extent to which a country's legal system can enforce financial contracts among its residents so that they can use these contracts to insure against idiosyncratic risks.

In our model, the state of development of a country's legal system is represented by the fraction of individual income that the country's 


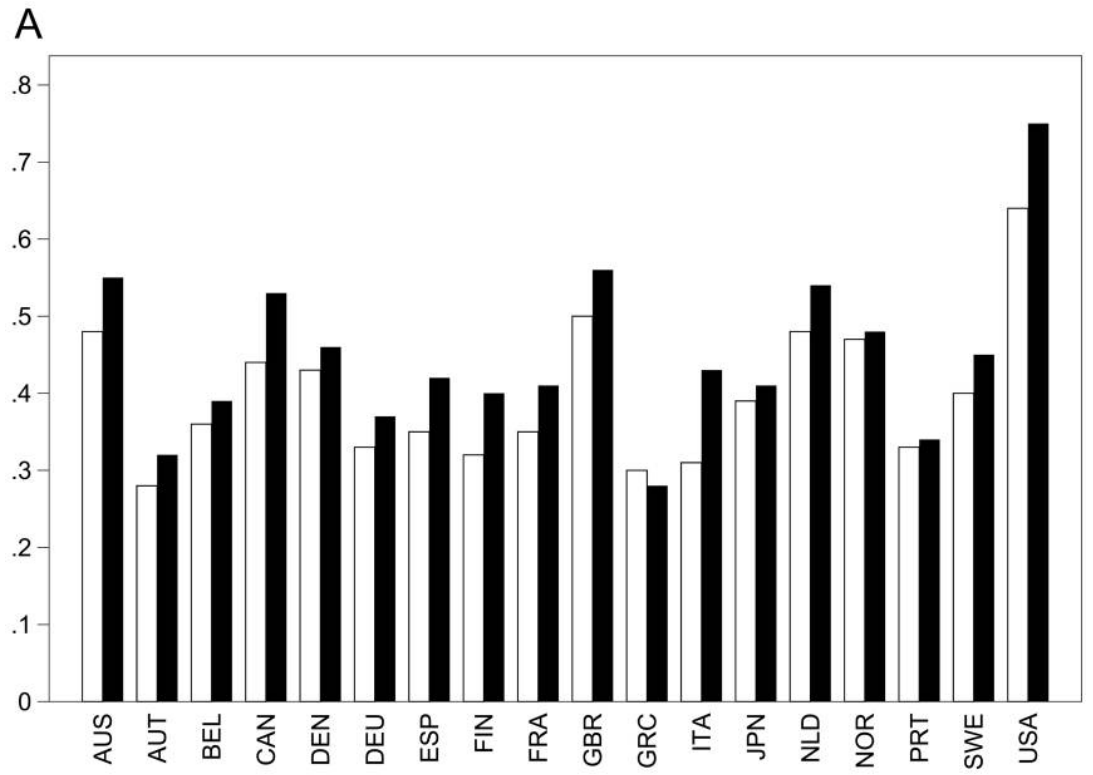

B

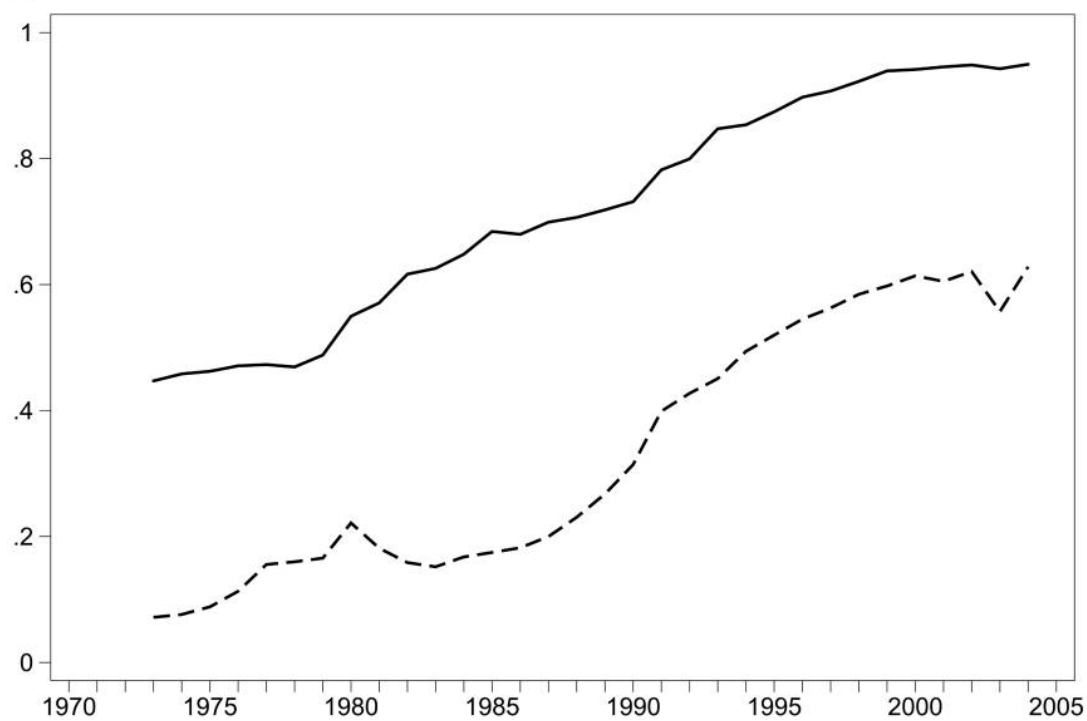

Fig. 1.- Indices of financial markets heterogeneity. $A$, Financial index score for advanced economies (data from IMF [2006]). Open bars $=1995$; black bars $=2004$. B, Index of financial liberalization (data from Abiad et al. [2008]). Solid line = OECD countries; dashed line = emerging economies. See Appendix A for definitions of the variables. 

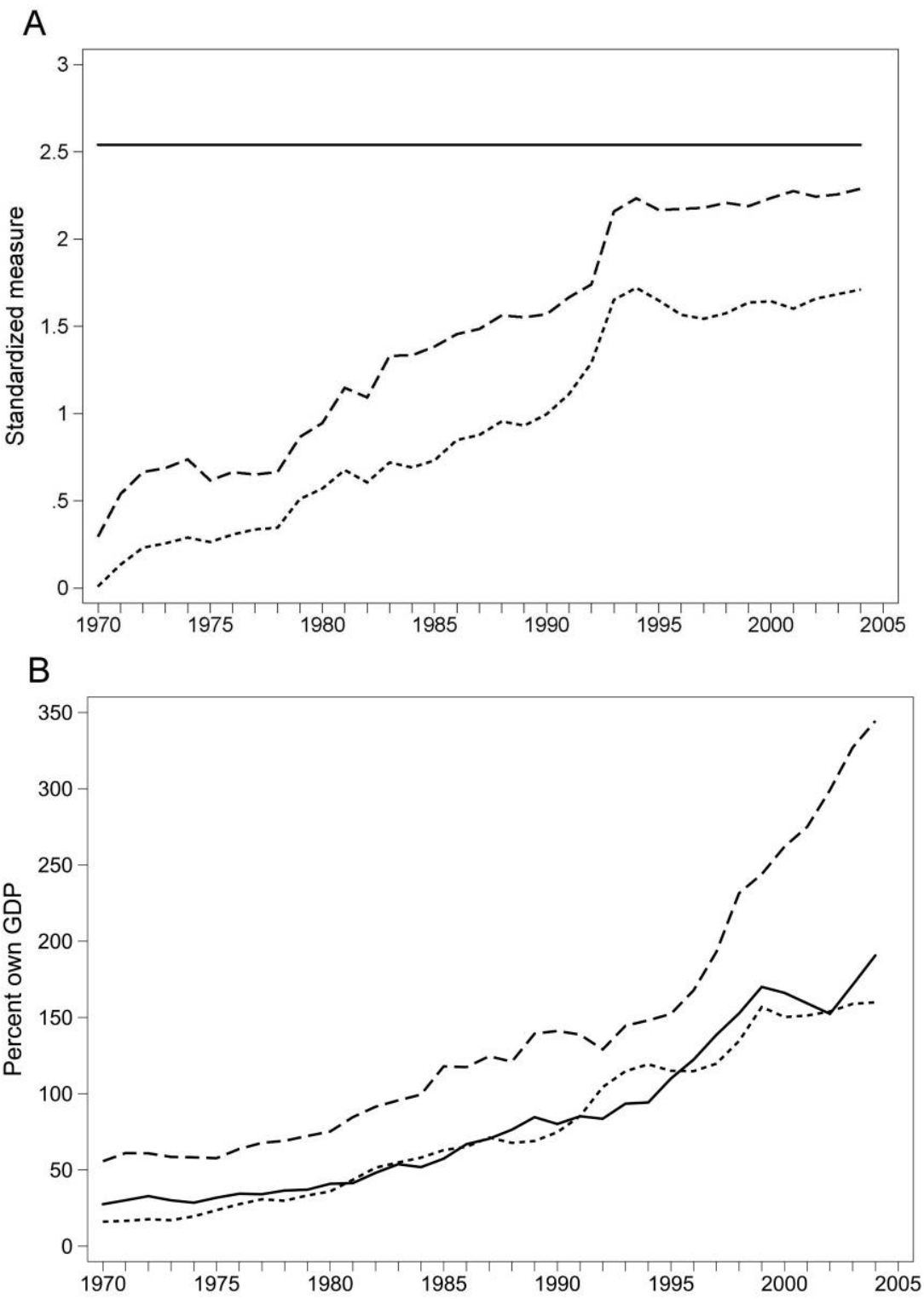

FIG. 2.-Indices of financial openness. $A$, Index of capital account openness (data from Chinn and Ito [2005]). Solid line $=$ United States; dashed line $=$ OECD countries except United States; dotted line $=$ all countries except United States. $B$, Gross stock of foreign assets and liabilities (data from Lane and Milesi-Ferretti [2007]). Solid line $=$ United States; dashed line = OECD countries except United States; dotted line = emerging economies. See Appendix A for definitions of the variables. 

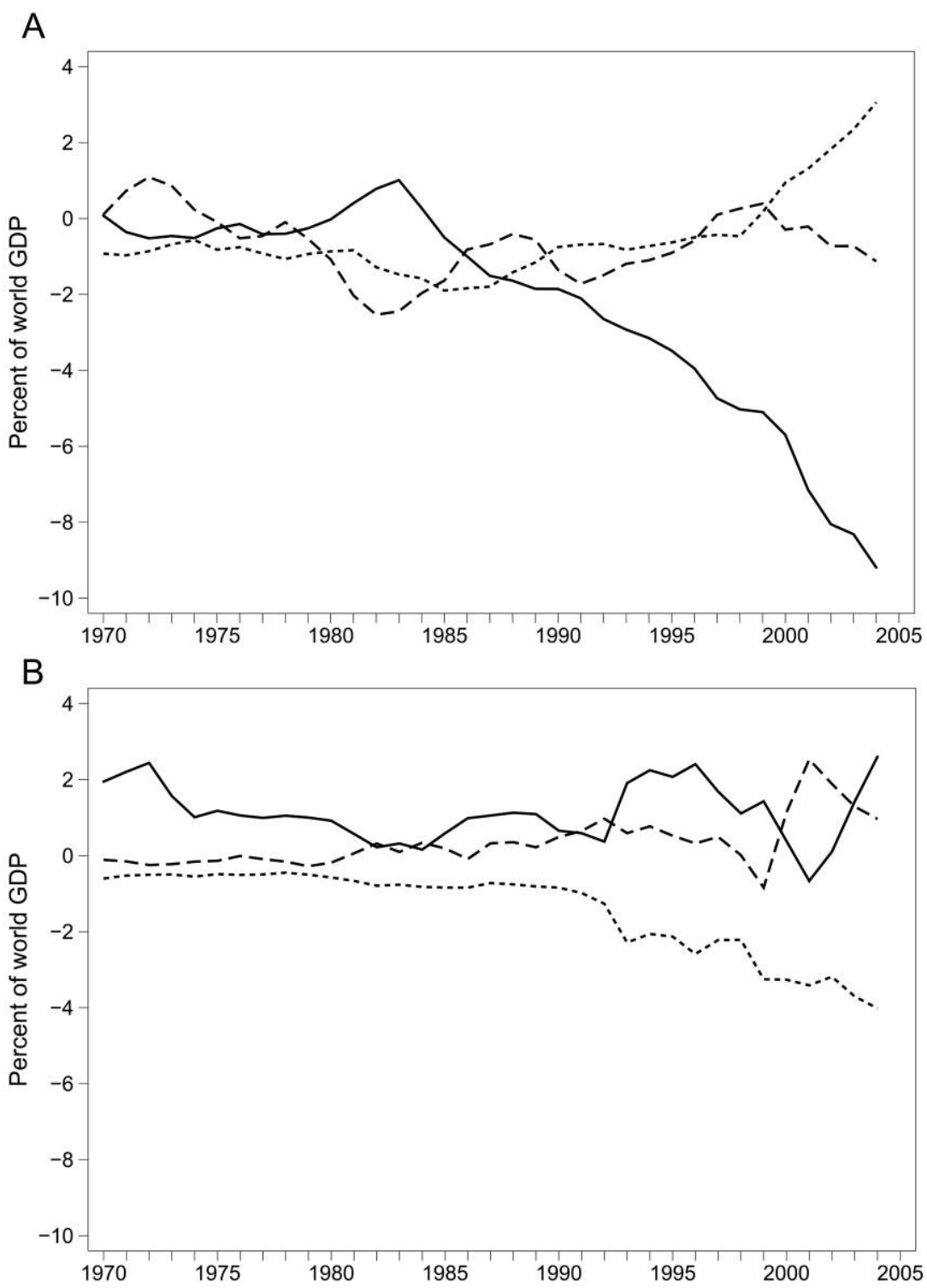

FIG. 3.-Net foreign asset positions in debt instruments and risky assets. $A$, NFA in debt and international reserves. $B$, NFA in portfolio equity and FDI. Data from Lane and MilesiFerretti (2007). Solid line $=$ United States; dashed line $=$ OECD countries except United States; dotted line $=$ emerging economies. See Appendix A. 
residents can divert from creditors. In autarky, countries with better legal systems, or that are more financially developed, attain lower average wealth-to-income ratios and higher interest rates. Upon financial liberalization, interest rates are equalized across countries, but the gap in their wealth-to-income ratios widens significantly. The latter occurs after a protracted process that takes several years to be completed and that is responsible for large, sustained declines in NFA positions like the one experienced by the United States. We show that moderate differences in financial development can easily lead to NFA positions larger than half of domestic production. Moreover, the adjustment process of NFA can take more than 30 years.

A second key feature that characterizes the legal systems is that enforcement is "residence based." That is, the enforcement of financial contracts is determined by the law of the country where the agent resides. Alternatively, "source-based" enforcement would imply that the enforcement of financial contracts is determined by the law of the country where the incomes are generated. With residence-based enforcement, our model can explain not only the change in overall NFA positions but also their portfolio structure (i.e., the most financially developed country has a large, negative NFA position, but it also has positive net holdings of nondiversifiable equity and large, negative net holdings of riskless bonds). Our quantitative analysis shows that this is indeed the case for economies that resemble the United States vis-à-vis the rest of the world. Moreover, a three-country extension of the model accounts for both the large negative NFA position of the United States and the differences in portfolio structures across the United States, other industrial countries, and emerging economies.

The premise that differences in domestic financial markets can produce external imbalances has precedent in the literature. Willen (2004) studied the qualitative predictions of a two-period endowment-economy model with exponential utility and normal-i.i.d. (independent and identically distributed) shocks. He showed that, under incomplete markets, trade imbalances emerge because of reduced savings by the agents residing in countries with "more complete" asset markets. Our model embodies this mechanism but differs in two key respects. First, we allow for endogenous production with "production risks," which is necessary for explaining the composition of asset portfolios. Second, we study an infinite horizon model with standard constant relative risk aversion preferences, exploring both the qualitative and quantitative predictions of the model.

Caballero et al. (2008) also emphasize the role of heterogeneous domestic financial systems in explaining global imbalances, but using a model in which financial imperfections are captured by a country's ability to supply assets in a world without uncertainty. In our framework, 
instead, financial imperfections have a direct impact on savings and, therefore, on the demand for assets. Uncertainty is crucial in our framework: without risk there are no imbalances, even if financial markets are heterogeneous. The two papers also differ in the main driving forces of global imbalances. In Caballero et al., the imbalances are generated by differential shocks to productivity growth and/or to the financial structure of countries. Our explanation relies instead on the integration of capital markets, given the differences in the characteristics of domestic financial markets.

Our work is also related to studies that investigate global imbalances with quantitative dynamic general equilibrium models (see Hunt and Rebucci 2005; IMF 2005; Faruqee, Laxton, and Pesenti 2007). In these studies, global imbalances emerge as the outcome of a combination of exogenous shocks, such as a permanent increase in the U.S. fiscal deficit, a permanent decline in the rate of time preference in the United States, and a permanent increase in foreign demand for U.S. financial assets. In contrast, our model predicts a reduction in U.S. savings and an increase in the foreign demand for U.S. assets endogenously, after financial integration, because of the different characteristics of the U.S. financial system. This occurs even if all countries have identical preferences, resources, and production technologies.

The rest of the paper is organized as follows: Section II describes a basic two-country framework that we use to characterize analytically the key theoretical results. Section III extends the basic model to make it suitable to map it to the data. Section IV conducts the quantitative analysis and identifies the winners and losers from financial liberalization. Section V compares the implications of our assumption of residence-based enforcement with different variants of source-based enforcement. We find that if enforcement of financial contracts involving international payments is fully source based in all countries, our model still accounts for large negative positions in NFA and riskless assets in the most financially developed country, but it does produce positive net holdings of risky assets in that country. However, mixed environments that combine source- and residence-based enforcement, which are likely to be more realistic, support equilibria with positive net foreign equity positions in the most financially developed country. Section VI extends our notion of financial development to allow for differences in borrowing limits. This allows the model to account for differences in portfolio structures across the United States, other industrial countries, and emerging economies. This section also shows that the results can be extended to the case in which there are differences in growth rates and income volatility across countries. Section VII presents conclusions. 


\section{A Model of Financial Globalization with Financial Heterogeneity}

We now describe a simple version of the model that illustrates the key properties analytically. These properties are preserved in the general setup we will use in the quantitative analysis.

Consider an economy composed of two countries, $i \in\{1,2\}$, inhabited by a continuum of agents of total mass one. Agents maximize the expected lifetime utility $E \sum_{t=0}^{\infty} \beta^{t} U\left(c_{t}\right)$, where $c_{t}$ is consumption at time $t$ and $\beta$ is the discount rate. The utility function is strictly increasing and concave with $U(0)=-\infty$ and $U^{\prime \prime \prime}(c)>0$.

Each country is endowed with a unit of a nonreproducible, internationally immobile asset, traded at price $P_{t}^{i}$. This asset can be used by each agent in the production of a homogeneous good, with a one-period gestation lag. Thus, the individual production function is $y_{t+1}=z_{t+1} k_{t}^{v}$, where $k_{t}$ is the quantity of the asset used at time $t, z_{t+1}$ is a projectspecific idiosyncratic discrete shock, and $y_{t+1}$ is the output produced at time $t+1$. We refer to $z_{t+1}$ as an investment shock because it determines the ex post return on the investment $k_{t}$.

We assume that $\nu<1$; that is, individual production displays decreasing returns to scale. This property derives from the assumption that production also requires the input of managerial or organizational capital, of which agents have limited supply. Managerial capital cannot be divided among multiple projects, but it is internationally mobile. Therefore, with capital mobility agents can choose to operate at home, buying the domestic productive asset, or abroad, buying the foreign productive asset. Without capital mobility, agents can buy only the productive asset located at home. ${ }^{3}$

Agents also receive income in the form of an idiosyncratic stochastic endowment, $w_{t}$, that follows a discrete Markov process. Therefore, there are two types of risk due to endowment and investment shocks. We can interpret $w_{t}$ as labor income and $y_{t}$ as capital income.

The impact of endowment shocks is beyond the control of individual agents, whereas that of investment shocks can be avoided by choosing not to purchase the productive asset. With this difference at play, we can distinguish risky from riskless investments so that agents face a nontrivial portfolio choice. We can then study not only how financial market heterogeneity affects net foreign asset positions but also their composition.

\footnotetext{
${ }^{3}$ The limited supply of the productive asset is similar to Lucas's tree model with two important differences. First, the tree or the fruits of the tree are combined with another input of production, the managerial capital. This introduces decreasing returns to scale. Second, shocks to production, which can also be interpreted as shocks to the fruits of the tree, are project-specific and therefore "idiosyncratic." In the typical Lucas's tree model, the realizations of the shocks are the same for all agents operating in the same country; i.e., there are only "aggregate" shocks.
} 
Note that production is individually run and shocks are idiosyncratic: there are no aggregate shocks. Therefore, cross-country sharing of aggregate risks is not an issue here. Also notice that there is no aggregate accumulation of capital. For an extension with capital accumulation, see Mendoza, Quadrini, and Ríos-Rull (2008).

Let $s_{t} \equiv\left(w_{t}, z_{t}\right)$ be the pair of endowment and investment shocks with a Markov transition process denoted by $g\left(s_{t}, s_{t+1}\right)$. Agents can buy contingent claims, $b\left(s_{t+1}\right)$, that depend on the next period's realizations of these shocks. Because there is no aggregate uncertainty, the price of one unit of consumption goods contingent on the realization of $s_{t+1}$ is $q_{t}^{i}\left(s_{t}, s_{t+1}\right)=g\left(s_{t}, s_{t+1}\right) /\left(1+r_{t}^{i}\right)$, where $r_{t}^{i}$ is the equilibrium interest rate.

Define $a_{t}$ as the end-of-period net worth before consumption. The budget constraint for an individual agent is

$$
a_{t}=c_{t}+k_{t} P_{t}^{i}+\sum_{s_{t+1}} b\left(s_{t+1}\right) q_{t}^{i}\left(s_{t}, s_{t+1}\right),
$$

and the agent's net worth evolves according to

$$
a\left(s_{t+1}\right)=w_{t+1}+k_{t} P_{t+1}^{i}+z_{t+1} k_{t}^{v}+b\left(s_{t+1}\right) .
$$

If asset markets were complete, that is, without restrictions on the set of feasible claims, agents would be able to perfectly insure against all risks. However, there are market frictions, and the set of feasible claims is constrained in each country. In particular, we assume that contracts are not perfectly enforceable because of the limited (legal) verifiability of shocks. Because of the limited verifiability, agents can divert part of their incomes from endowment and production, but they lose a fraction $\phi^{i}$ of the diverted income. The parameter $\phi^{i}$ characterizes the degree of enforcement of financial contracts in country $i$. This is the only feature that differentiates the two countries.

We also assume that there is limited liability and agents cannot be excluded from the market after defaulting. Under these assumptions, Appendix B shows that contract enforceability imposes the following two constraints:

$$
a\left(s_{n}\right)-a\left(s_{1}\right) \geq\left(1-\phi^{i}\right) \cdot\left[\left(w_{n}+z_{n} k_{t}^{\nu}\right)-\left(w_{1}+z_{1} k_{t}^{\nu}\right)\right]
$$

and

$$
a\left(s_{n}\right) \geq 0
$$

for all $n \in\{1, \ldots, N\}$. Here $n$ is the index for a particular realization of the two shocks with $s_{1}$ the lowest (worst) realization. The number of all possible realizations is $N$.

The first condition requires that the variation in net worth, $a\left(s_{n}\right)-$ $a\left(s_{1}\right)$, cannot be smaller than the variation in income, scaled by $1-$ $\phi^{i}$. This constraint can also be written in terms of the contingent claims. 
From the definition of $a\left(s_{t+1}\right)$ provided in (2), the constraint (3) can be rewritten as

$$
b\left(s_{n}\right)-b\left(s_{1}\right) \geq-\phi^{i} \cdot\left[\left(w_{n}+z_{n} k_{t}^{\nu}\right)-\left(w_{1}+z_{1} k_{t}^{\nu}\right)\right] .
$$

When $\phi^{i}$ is positive, agents can choose unequal amounts of contingent claims, and therefore, they can get some insurance. If $\phi^{i}$ is sufficiently large, agents can achieve full insurance. When $\phi^{i}=0$-implying that income can be diverted without losses-only non-state-contingent claims are feasible. Constraint (4) imposes that net worth cannot be negative. This follows from the assumption of limited liability.

A key assumption is that $\phi^{i}$ pertains to the country of residence of the agents, regardless of the geographic location of their assets. In particular, if asset markets are globally integrated, domestic agents can buy foreign productive assets and receive foreign income, but still their access to insurance is determined by the domestic, not the foreign, $\phi$. This implies that the ability of an agent to divert investment incomes generated abroad depends on the legal environment of the country of residence.

This assumption is based on the idea that the verification of diversion requires the verification of individual consumption. Because individual consumption takes place in the country of residence, the institutional features of the country of residence are the ones that matter for enforcement. ${ }^{4}$ Section V explores the extent to which our results are robust to alternative assumptions about the residence or source nature of $\phi^{i}$.

\section{A. Optimization Problem and Equilibrium}

Let $\left\{P_{\tau}^{i}, q_{\tau}^{i}\left(s_{\tau}, s_{\tau+1}\right)\right\}_{\tau=t}^{\infty}$ be a (deterministic) sequence of prices in country $i$. With capital mobility these prices are equalized internationally, and therefore, an individual agent is indifferent about the domestic versus foreign location of the productive investment. We can then write the optimization problem of an individual agent as if he or she buys only domestic $k$. Independently of the international capital mobility regime, this can be written as

$$
V_{t}^{i}(s, a)=\max _{c, k, b\left(s^{\prime}\right)}\left\{U(c)+\beta \sum_{s^{\prime}} V_{t+1}^{i}\left(s^{\prime}, a\left(s^{\prime}\right)\right) g\left(s, s^{\prime}\right)\right\}
$$

subject to (1), (2), (3), and (4), where we denote current "individual" variables without subscripts and next period individual variables with the prime superscript. Notice that this is the optimization problem for

\footnotetext{
${ }^{4}$ One way to think about this assumption is that agents have the ability to repatriate the incomes earned abroad. Once the incomes are transferred back to the home country, the verifiability of these incomes is determined by the institutions at home.
} 
any deterministic sequence of prices, not only steady states. This motivates the time subscript in the value function.

The solution to the agent's problem yields decision rules for consumption, $c_{t}^{i}(s, a)$, productive assets, $k_{t}^{i}(s, a)$, and contingent claims, $b_{t}^{i}\left(s, a, s^{\prime}\right)$. Since in the equilibrium with capital mobility agents are indifferent about the location of the productive investment, we do not have to specify whether the holding of productive capital, $k_{t}^{i}(s, a)$, is domestic or foreign. The decision rules determine the evolution of the distribution of agents over $s, k$, and $b$, which we denote by $M_{t}^{i}(s, k, b)$.

Definition 1 (Financial autarky). Given the financial development indicator, $\phi^{i}$, and initial wealth distributions, $M_{t}^{i}(s, k, b)$, for $i \in\{1,2\}$, an equilibrium without international mobility of capital is defined by sequences of $(a)$ agents' policies $\left\{c_{\tau}^{i}(s, a), k_{\tau}^{i}(s, a), b_{\tau}^{i}\left(s, a, s^{\prime}\right)\right\}_{\tau=t}^{\infty},(b)$ value functions $\left\{V_{\tau}^{i}(s, a)\right\}_{\tau=t}^{\infty},(c)$ prices $\left\{P_{\tau}^{i}, r_{\tau}^{i}, q_{\tau}^{i}\left(s, s^{\prime}\right)\right\}_{\tau=t}^{\infty}$, and $(d)$ distributions $\left\{M_{\tau}^{i}(s, k, b)\right\}_{\tau=t+1}^{\infty}$ such that (i) the policy rules solve problem (6) and $\left\{V_{\tau}^{i}(s, k)\right\}_{\tau=t}^{\infty}$ are the associated value functions; (ii) prices satisfy $q_{\tau}^{i}=$ $g\left(s, s^{\prime}\right) /\left(1+r_{t}^{i}\right)$; (iii) asset markets clear,

$$
\begin{gathered}
\int_{s, k, b} k_{\tau}^{i}(s, a) M_{\tau}^{i}(s, k, b)=1, \\
\int_{s, k, b, s^{\prime}} b_{\tau}^{i}\left(s, a, s^{\prime}\right) M_{\tau}^{i}(s, k, b) g\left(s, s^{\prime}\right)=0
\end{gathered}
$$

for each $i \in\{1,2\}$ and $\tau \geq t$; and (iv) the sequence of distributions is consistent with the initial distributions, the individual policies, and the stochastic processes for the idiosyncratic shocks.

The definition of the equilibrium with globally integrated capital markets is similar, except for the prices and market-clearing conditions ii and iii. With financial integration there is a global market for assets and asset prices are equalized across countries. Therefore, condition ii becomes

$$
q_{\tau}^{1}=\frac{g\left(s, s^{\prime}\right)}{1+r_{t}^{1}}=\frac{g\left(s, s^{\prime}\right)}{1+r_{t}^{2}}=q_{\tau}^{2}
$$

and $P_{\tau}^{1}=P_{\tau}^{2}$. Furthermore, asset markets clear globally instead of country by country. Therefore, the market-clearing condition for the productive assets becomes

$$
\sum_{i=1}^{2} \int_{s, k, b} k_{\tau}^{i}(s, a) M_{\tau}^{i}(s, k, b)=2
$$


and the market-clearing condition for contingent claims becomes

$$
\sum_{i=1}^{2} \int_{s, k, b, s^{\prime}} b_{\tau}^{i}\left(s, a, s^{\prime}\right) M_{\tau}^{i}(s, k, b) g\left(s, s^{\prime}\right)=0 .
$$

With capital mobility, the assets owned by a country are no longer equal to the assets located in the country, and hence NFA positions are generally different from zero. Consequently, since at equilibrium agents are indifferent about the location of the productive investment, only the "net" share of the foreign productive asset is determined. The same holds for the contingent claims. Therefore, the net foreign asset position of country $i$ is given by

$$
\begin{aligned}
\mathrm{NFA}_{\tau}^{i}= & \int_{s, k, b, s^{\prime}} b_{\tau}^{i}\left(s, a, s^{\prime}\right) g\left(s, s^{\prime}\right) M_{\tau}^{i}(s, k, b) \\
& +\int_{s, k, b}\left[k_{\tau}^{i}(s, a)-1\right] P_{\tau} M_{\tau}^{i}(s, k, b) .
\end{aligned}
$$

The first term on the right-hand side is the net position in "contingent claims." The second is the net position in "productive assets." We refer to the first term as bond position or international lending when positive and debt position or borrowing when negative.

\section{B. Equilibria with and without Capital Mobility}

This subsection characterizes the properties of the equilibrium with and without financial integration. To clarify the different roles played by endowment and investment shocks, we consider separately the cases with only endowment risks and with only investment risks.

\section{Endowment Shocks Only}

Assume that $z$ is not stochastic $(z=\bar{z})$, so that there are only endowment shocks. Denote by $\bar{\phi}$ a sufficiently high value of the enforcement parameter so that (3) is not binding and hence markets are complete. With i.i.d. shocks, $\bar{\phi}=1$ suffices, whereas persistent shocks require $\bar{\phi}>1$. To show the importance of domestic financial development, we compare the limiting cases of complete markets $(\phi=\bar{\phi})$ with the environment without state-contingent claims $(\phi=0)$. We first look at the autarky regime and then at the financially integrated regime. 
When $\phi=\bar{\phi}$, constraint (3) is not binding by assumption. Therefore, the first-order conditions of problem (6) with respect to $k$ and $b\left(w^{\prime}\right)$ are

$$
U^{\prime}(c)=\beta\left(1+r_{t}\right) U^{\prime}\left(c\left(w^{\prime}\right)\right)+\left(1+r_{t}\right) \lambda\left(w^{\prime}\right) \quad \forall w^{\prime}
$$

and

$$
U^{\prime}(c)=\beta R_{t+1}(k, \bar{z}) E U^{\prime}\left(c\left(w^{\prime}\right)\right)+R_{t+1}(k, \bar{z}) E \lambda\left(w^{\prime}\right),
$$

where $\lambda\left(w^{\prime}\right)$ is the Lagrange multiplier associated with the limited liability constraint (4), and $R_{t+1}(k, \bar{z})=\left(P_{t+1}+\nu \bar{z} k^{\nu-1}\right) / P_{t}$ is the gross marginal return from the productive asset. Notice that $R_{t+1}(k, \bar{z})$ is decreasing in $k$.

Since in this case agents have complete insurance, condition (7) holds for any realization of $w^{\prime}$, which implies that next period consumption $c\left(w^{\prime}\right)$ is the same for all $w^{\prime}$. Moreover, conditions (7) and (8) imply $R_{t+1}(k, \bar{z})=1+r_{t}$, so the marginal return on the productive asset is equal to the interest rate. Because $R_{t+1}(k, \bar{z})$ is strictly decreasing in $k$, this implies that all agents choose the same input of the productive asset, that is, $k=1$. Given that the supply of the productive asset is fixed, total output is also fixed. We now establish that the full insurance autarky equilibrium must satisfy $\beta\left(1+r_{t}\right)=1$.

Lemma 1. Under the financial autarky regime and $\phi=\bar{\phi}$, the interest rate and the price of the productive asset are constant and equal to $r=1 / \beta-1$ and $P=\nu \bar{z} / r$, respectively.

Proof. By way of contradiction, if $\beta\left(1+r_{t}\right) \neq 1$, condition (7) implies that consumption growth of all agents is either positive or negative. This cannot be an equilibrium because aggregate output remains constant. Therefore, $r_{t}=1 / \beta-1=r$. Because all agents use the same units of the productive asset, $k=1$, conditions (7) and (8) imply $\left(P_{t+1}+\right.$ $\nu \bar{z}) / P_{t}=1+r$. The only stationary solution for this difference equation is $P_{t}=P_{t+1}=\nu \bar{z} / r$. QED

Consider next the case of an economy in financial autarky but with $\phi=0$. The enforceability constraint (3) imposes that $b\left(w_{1}\right)=\cdots=$ $b\left(w_{N}\right)=b$; that is, assets cannot be state-contingent. The first-order conditions are

$$
U^{\prime}(c)=\beta\left(1+r_{t}\right) E U^{\prime}\left(c\left(w^{\prime}\right)\right)+\left(1+r_{t}\right) E \lambda\left(w^{\prime}\right)
$$

and

$$
U^{\prime}(c)=\beta R_{t+1}(k, \bar{z}) E U^{\prime}\left(c\left(w^{\prime}\right)\right)+R_{t+1}(k, \bar{z}) E \lambda\left(w^{\prime}\right) .
$$

These conditions still imply that $R_{t+1}(k, \bar{z})=1+r_{t}$, and the input of the productive asset is the same for all agents. Thus, all agents receive the same investment income. However, the absence of state-contingent 
assets implies that the endowment risk cannot be insured and individual consumption is not constant. It varies with the realization of the endowment as in the standard Bewley (1986) economy. As is known from the savings literature (see Huggett 1993; Aiyagari 1994; Carroll 1997), the uninsurability of the idiosyncratic risk generates precautionary savings and in the steady state $\beta(1+r)<1$. Formally, we have the following lemma.

Lemma 2. Under the financial autarky regime and $\phi=0$, the interest rate satisfies $r_{t}<1 / \beta-1$ and the steady-state price is $P=\nu \bar{z} / r$.

The proof is standard and uses convexity of marginal utility together with the fact that all households employ the same amount of productive asset.

Using these lemmas, we can compare countries in financial autarky at different stages of financial development: The country with a lower degree of financial development $(\phi=0)$ has a lower interest rate and, at least in the steady state, a higher asset price than a more financially developed country.

Consider now the steady-state equilibrium of an economy in which there is perfect mobility of capital between country 1 (henceforth C1), characterized by $\phi^{1}=\bar{\phi}$, and country 2 (henceforth C2), characterized by $\phi^{2}=0$. In this case, the perfect substitutability of assets implies that their prices are equated across countries, and so are the world interest rate and the holdings of productive assets by all agents. Given that C1 has no need for precautionary savings but C2 does, the conflict gets resolved by households in C1 hitting the limited liability constraint (4). The following proposition formalizes this result.

Proposition 1. Suppose that $\phi^{1}=\bar{\phi}$ and $\phi^{2}=0$. In the equilibrium with financial integration, $r_{t}<1 / \beta-1$, and $\mathrm{C} 1$ accumulates a negative NFA position but holds a zero net position in the productive asset.

Proof. See Appendix C.

This proposition holds only for the limiting cases of $\phi^{1}=\bar{\phi}$ and $\phi^{2}=0$. However, we can infer the properties of the equilibrium for intermediate values of $\phi$ (i.e., for any case $0 \leq \phi^{2}<\phi^{1}<\bar{\phi}$ ). In general, lower values of $\phi$ increase precautionary savings and reduce the equilibrium interest rate. Therefore, once the capital markets are liberalized, the country with a lower value of $\phi$ accumulates a positive NFA position.

This point is illustrated in figure 4 . The figure plots the aggregate demand for assets (supply of savings) in each country as an increasing function of $r .^{5}$ Country 1 has deeper financial markets $\left(\phi^{1}>\phi^{2}\right)$ and

\footnotetext{
${ }^{5}$ The asset demand curves in fig. 4 correspond to the well-known average asset demand curve from the closed-economy heterogeneous agents literature (e.g., Aiyagari 1994). Average asset demand approaches infinity as the interest rate converges to the rate of time preference from below. The reason is that agents need an infinite amount of precautionary savings to attain a level of consumption that is not stochastic.
} 

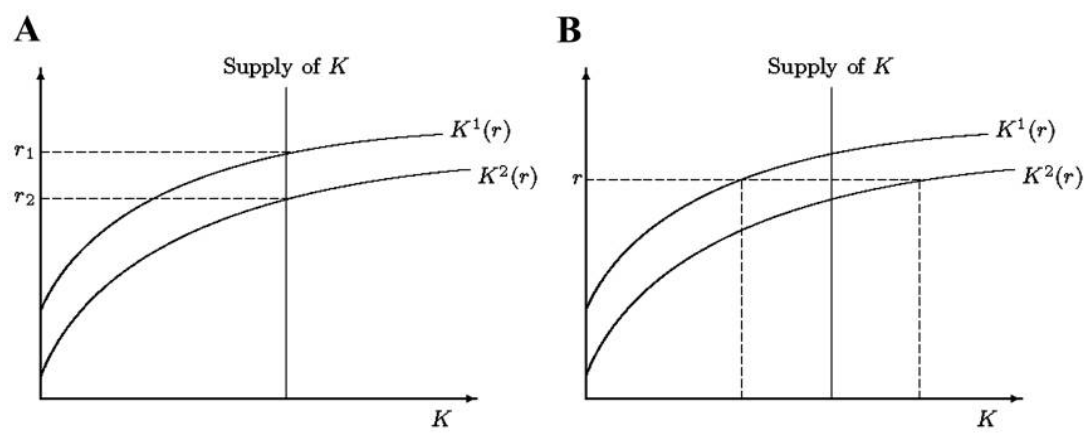

Fig. 4.-Steady-state equilibria with heterogeneous financial conditions: $A$, autarky; $B$, mobility.

hence lower asset demand for each interest rate. Because the supply of the productive asset is fixed, aggregate net savings (in units of $K$ ) must be zero under autarky in each country. This requires a higher interest rate in $\mathrm{C} 1\left(r^{1}>r^{2}\right)$.

\section{Investment Shocks Only}

We now consider the case in which the productivity $z$ is stochastic whereas the endowment is constant at $w=\bar{w}$. This assumption allows us to distinguish debt instruments from risky investments such as FDI. As before, we compare equilibria under autarky and under financial integration for the limiting cases of $\phi=\bar{\phi}$ and $\phi=0$.

The first-order conditions in autarky for an economy with $\phi=\bar{\phi}$ are

$$
U^{\prime}(c)=\beta\left(1+r_{t}\right) U^{\prime}\left(c\left(z^{\prime}\right)\right)+\left(1+r_{t}\right) \lambda\left(z^{\prime}\right) \quad \forall z^{\prime}
$$

and

$$
U^{\prime}(c)=\beta E R_{t+1}\left(k, z^{\prime}\right) U^{\prime}\left(c\left(z^{\prime}\right)\right)+E \lambda\left(z^{\prime}\right) R_{t+1}\left(k, z^{\prime}\right) .
$$

The first condition holds for all realizations of $z^{\prime}$. Therefore, the next period's consumption, $c\left(z^{\prime}\right)$, must be the same for all realizations of $z^{\prime}$ (full insurance). Because next period's consumption is not stochastic, conditions (11) and (12) imply that $E R_{t+1}\left(k, z^{\prime}\right)=1+r_{t}$. Therefore, there is no marginal premium for investing in the productive asset and $k$ is the same for all agents. Thus, lemma 1 also applies here and the only equilibrium is characterized by $\beta\left(1+r_{t}\right)=1$. Intuitively, because agents can insure perfectly against the idiosyncratic risk, there are no precautionary savings and in equilibrium the interest rate must be equal to the intertemporal discount rate.

In an economy with $\phi=0$, the incentive-compatibility constraint (3) 
imposes that $b\left(z_{1}\right)=\cdots=b\left(z_{N}\right)=b$; that is, claims cannot be state contingent. The first-order conditions are

$$
U^{\prime}(c)=\beta\left(1+r_{t}\right) E\left[U^{\prime}\left(c\left(z^{\prime}\right)\right)\right]+\left(1+r_{t}\right) E\left[\lambda\left(z^{\prime}\right)\right]
$$

and

$$
U^{\prime}(c)=\beta E\left[U^{\prime}\left(c\left(z^{\prime}\right)\right) R_{t+1}\left(k, z^{\prime}\right)\right]+E\left[\lambda\left(z^{\prime}\right) R_{t+1}\left(k, z^{\prime}\right)\right] .
$$

Lemma 2 also applies here; hence, the equilibrium interest rate is smaller than the intertemporal discount rate. The main difference with the case of endowment shocks is that now there is a marginal risk premium for the risky asset. In particular, if the borrowing limit is not binding, conditions (13) and (14) yield the standard equation for the risk premium:

$$
E R_{t+1}\left(k, z^{\prime}\right)-\left(1+r_{t}\right)=-\frac{\operatorname{Cov}\left[R_{t+1}\left(k, z^{\prime}\right), U^{\prime}\left(c\left(z^{\prime}\right)\right)\right]}{E U^{\prime}\left(c\left(z^{\prime}\right)\right)},
$$

which is positive as long as $U^{\prime}\left(c\left(z^{\prime}\right)\right)$ is negatively correlated with $R_{t+1}\left(k, z^{\prime}\right)$.

Now suppose that the two countries become financially integrated. The first country has $\phi^{1}=\bar{\phi}$ and the second $\phi^{2}=0$. The following proposition characterizes the steady state.

Proposition 2. Suppose that $\phi^{1}=\bar{\phi}$ and $\phi^{2}=0$. In the steady state with financial integration, $r<1 / \beta-1$. Country 1 has a negative NFA position but a positive position in the productive asset. The average return of C1's foreign assets is larger than the cost of its liabilities.

Proof. See Appendix C.

The proposition shows that, with investment shocks, countries with deeper financial markets invest in foreign (high-return) assets and finance this investment with foreign debt. In the particular case in which the most developed country has $\phi^{1}=\bar{\phi}$, proposition 1 guarantees that this country ends up with a negative NFA position. The higher return derives from the decreasing returns property of the production function. This generates a surplus that compensates the agent's managerial capital.

Consider now the general case with $0 \leq \phi^{2}<\phi^{1}<\bar{\phi}$. Country 1 has a greater (yet imperfect) ability to insure than C2, and hence it will still buy some of C2's risky asset, ${ }^{6}$ even if it is not always true that it accumulates a negative NFA position. Moreover, the imperfect insurance generates a marginal risk premium even for $\mathrm{Cl}$, which is the rationale

\footnotetext{
${ }^{6}$ The concavity of the production function is crucial for this result. With a linear technology, as in Angeletos (2007), the most developed country would own all of the world's risky assets. As a result, the less developed country would have fewer incentives to save.
} 
for the higher return that $\mathrm{C} 1$ collects from its foreign investments relative to the cost of its foreign liabilities.

\section{Endowment and Investment Shocks}

With both endowment and investment shocks, the first-order conditions are also given by (11)-(14). The only difference is that next period's consumption depends on both shocks, that is, $c\left(s^{\prime}\right)$. The autarky equilibria are also characterized by lemmas 1 and 2. The following proposition characterizes the equilibrium under global financial integration.

Proposition 3. Suppose that $\phi^{1}=\bar{\phi}$ and $\phi^{2}=0$. In the steady state with perfect capital mobility, $r<1 / \beta-1$. Country 1 has a negative NFA position but a positive position in foreign productive assets. The average return of C1's foreign ownership is bigger than the cost of its liabilities.

Proof. $\quad$ Same as in proposition 2.

This is a restatement of proposition 2 for the case with both shocks. In the extreme case with $\phi^{1}=\bar{\phi}$ and $\phi^{2}=0$, the addition of endowment shocks does not change the main properties of the equilibrium. In the general case, the interest rate is smaller than the intertemporal discount rate, and $\mathrm{C} 1$ acquires a positive net position in foreign productive assets, but its NFA position is not necessarily negative. This depends on the relative importance of the two shocks. As long as the endowment shock is sufficiently large, however, C1 will hold a negative NFA position.

\section{The General Model}

We now extend the basic setup presented in the previous section along two dimensions: (1) cross-country diversification of the investment risk and (2) differences in the economic size of countries. We also generalize the model to include any finite number of countries $I \geq 2$. These features allow for a richer quantitative analysis.

We introduce international risk diversification by assuming that managerial capital is now divisible across countries. Each agent is endowed with one unit of this capital. With $A_{j, t} \in[0,1]$ denoting the allocation of an agent's managerial capital in country $j$, the total (worldwide) production at time $t+1$ of the agent is equal to

$$
y_{t+1}=\sum_{j=1}^{I} z_{j, t+1} A_{j, t}^{1-\nu} k_{j, t}^{\nu}, \quad \text { with } \quad \sum_{j=1}^{I} A_{j, t}=1 .
$$

The variables $z_{j, t+1}$ and $k_{j, t}$ are, respectively, the project-specific idiosyncratic shock and the input of the productive asset in country $j$.

The divisibility of the managerial capital is the most important ex- 
tension. In the basic model, each agent had to choose allocating all the managerial capital either in C1 $\left(A_{1, t}=1\right.$ and $\left.A_{2, t}=0\right)$ or in C2 $\left(A_{1, t}=0\right.$ and $\left.A_{2, t}=1\right)$. In contrast, now agents can allocate any fraction $A_{j, t} \in[0,1]$ in each of the $I$ countries. This has two important implications. First, as long as the shocks $z_{j, t+1}$ are imperfectly correlated, financial integration allows agents to diversify investment risk across countries. ${ }^{7}$ Second, while in the basic model only the net foreign position in the productive asset was determined at equilibrium, now the gross positions are also determined.

Let $s_{t} \equiv\left(w_{t}, z_{1, t}, \ldots, z_{I, t}\right)$ be the endowment and investment shocks and $g\left(s_{t}, s_{t+1}\right)$ their transition probabilities. As in the basic model, agents can buy contingent claims, $b\left(s_{t+1}\right)$. The price of one unit of consumption goods contingent on the realization of $s_{t+1}$ is $q_{t}^{i}\left(s_{t}, s_{t+1}\right)=g\left(s_{t}\right.$, $\left.s_{t+1}\right) /\left(1+r_{t}^{i}\right)$, where $r_{t}^{i}$ is the equilibrium interest rate in country $i$.

Given the end-of-period net worth before consumption, $a_{t}$, the budget constraint is

$$
a_{t}=c_{t}+\sum_{j=1}^{I} k_{j, t} P_{t}^{j}+\sum_{s_{t+1}} b\left(s_{t+1}\right) q_{t}^{i}\left(s_{t}, s_{t+1}\right),
$$

and net worth evolves according to

$$
a\left(s_{t+1}\right)=w_{t+1}+\sum_{j=1}^{I}\left(k_{j, t} P_{t+1}^{j}+z_{j, t+1} A_{j, t}^{1-\nu} k_{j, t}^{v}\right)+b\left(s_{t+1}\right) .
$$

The features of the financial environment are the same as in the basic model: shocks are not verifiable and agents can divert part of the incomes from endowment and production, both domestic and abroad, but in the process they lose a fraction $\phi^{i}$ of the diverted income. As before, $\phi^{i}$ pertains to the residence of agents as opposed to the source of the income.

Following the same steps of Appendix B, the enforcement of financial contracts imposes the following constraints:

$$
a\left(s_{n}\right)-a\left(s_{1}\right) \geq\left(1-\phi^{i}\right) \cdot\left[w_{n}-w_{1}+\sum_{j=1}^{I}\left(z_{j, n}-z_{j, 1}\right) A_{j, t}^{1-\nu} k_{j, t}^{\nu}\right]
$$

and

$$
a\left(s_{n}\right) \geq 0
$$

for all $n \in\{1, \ldots, N\}$, where $N$ is the number of all possible realizations

\footnotetext{
${ }^{7}$ We are implicitly assuming that agents do not benefit from allocating their managerial capital to multiple operations within each country. The only diversification gains arise from cross-country diversification. Without loss of generality, we can interpret $z_{j, t+1}$ as the residual risk after exploiting all the diversification margins available within each country.
} 
of endowment and investment shocks and $s_{1}$ is the lowest (worst) realization. $^{8}$

There is a difference with the previous constraint (3). Now individual agents have both differentiated domestic and foreign incomes from productive investments. Before, all income from productive investments was subject to the same shock and hence could not be distinguished.

The last extension of the model relates to the economic size of countries participating in world capital markets. This is important for the quantitative properties of the model. Obviously, large imbalances for C1 can arise only if the economy of C2 is relatively large. In our model, differences in economic size could derive from differences in population and/or in productivity, that is, in the average value of the endowment $w$ and in the per capita supply of the productive asset $k$. However, for the properties we are interested in, what matters is differences in the aggregate economic size of countries, independently of the factors that account for them. Therefore, to simplify the analysis, we assume that differences in economic size derive only from differences in population.

We denote by $\mu^{i}$ the population share of country $i$ and continue to assume that the per capita endowment $w$ and the per capita domestic supply of the productive asset are the same in all countries. This extension does not alter the analytical results of Section II.

Optimization problem and equilibrium.-Given deterministic sequences of prices $\left\{\left\{P_{\tau}^{j}, q_{\tau}^{j}\left(s_{\tau}, s_{\tau+1}\right)\right\}_{\tau=U}^{\infty} J_{j=1}^{I}\right.$, a single agent's problem in country $i$ can be written as

$$
V_{t}^{i}(s, a)=\max _{A, k, b\left(s^{\prime}\right)}\left\{U(c)+\beta \sum_{s^{\prime}} V_{t+1}^{i}\left(s^{\prime}, a\left(s^{\prime}\right)\right) g\left(s, s^{\prime}\right)\right\}
$$

subject to (15), (16), (17), (18), and

$$
A_{j} \in[0,1], \quad \sum_{j=1}^{I} A_{j}=1 .
$$

The definition of the autarky equilibrium is equivalent to the definition provided for the basic model. The reason is that all the extensions introduced in this section matter only for the regime with capital mobility. With capital mobility the individual state variables are given by $(s, A, k, b)$. The variable $s$ is an $I+1$-dimensional vector containing the realization of the endowment plus the realizations of the investment shocks in each of the $I$ countries. The variables $A$ and $k$, without subscripts, are $I$-dimensional vectors containing, respectively, the allocation of managerial capital and the ownership of productive assets in each of

\footnotetext{
${ }^{8}$ A generic $s_{n}$ contains $1+I$ elements: the endowment shock $w_{n}$ and the realizations of the idiosyncratic shocks in each of the $I$ countries, i.e., $z_{j, n}$ for $j=1, \ldots, I$.
} 
the $I$ countries. Finally, the realized claim $b$ remains one-dimensional as in the simpler version of the model. The definition of the equilibrium with capital mobility is as follows.

Definition 2 (Financial integration equilibrium). Given the financial development indicator, $\phi^{i}$, and initial wealth distributions, $M_{t}^{i}(s$, $A, k, b)$, a general equilibrium with international capital mobility is defined by sequences of $(a)$ individual policies

$$
\left\{c_{\tau}^{i}(s, a), b_{\tau}^{i}\left(s, a, s^{\prime}\right),\left\{A_{j, \tau}^{i}(s, a), k_{j, \tau}^{i}(s, a)\right\}_{j=1}^{I}\right\}_{\tau=t}^{\infty},
$$

(b) value functions $\left\{V_{\tau}^{i}(s, a)\right\}_{\tau=t}^{\infty},(c)$ prices $\left\{\left\{P_{\tau}^{j}, r_{\tau}^{j}, q_{\tau}^{j}\left(s, s^{\prime}\right)\right\}_{j=1}^{I}\right\}_{\tau=t}^{\infty}$, and $(d)$ distributions $\left\{M_{\tau}^{i}(s, A, k, b)\right\}_{\tau=t+1}^{\infty}$ such that (i) the policy rules solve problem (19) with $\left\{V_{\tau}^{i}(s, a)\right\}_{\tau=t}^{\infty}$ as associated value functions; (ii) prices satisfy $q_{\tau}^{j}=g\left(s, s_{t}^{\prime j}\right)$; (iii) the global markets for the productive assets of each country clear,

$$
\sum_{i=1}^{I} \int_{s, A, k, b} k_{j, \tau}^{i}(s, a) M_{\tau}^{i}(s, A, k, b)=\mu^{j}
$$

for $j=1, \ldots, I$; (iv) the worldwide market for contingent claims clears,

$$
\sum_{i=1}^{I} \int_{s, A, k, b, s^{\prime}} b_{\tau}^{i}\left(s, a, s^{\prime}\right) M_{\tau}^{i}(s, A, k, b) g\left(s, s^{\prime}\right)=0 ;
$$

and (v) the sequence of distributions is consistent with the initial distributions, the individual policies, and the idiosyncratic shocks.

It is important to emphasize that, in general, the market-clearing conditions for productive assets do not lead to the equalization of their prices; that is, $P_{t}^{i}$ is not equal to $P_{t}^{j}$ for $i \neq j$. The reason is that unless the shocks are perfectly correlated across countries, agents are not indifferent about the composition of their portfolios of productive assets. This is in contrast to the equalization of the interest rates: all that matters for the choice of the contingent claims is their returns, which are determined by the interest rate.

It is possible to derive some analytical results for this general model that are similar to those of the basic model. The optimality conditions are analogous, except that now we also have the conditions characterizing the optimal cross-country allocation of managerial capital. These conditions are $k_{i} / A_{i}=k_{j} / A_{j}$ for all $j=1, \ldots, I$. If we consider the case in which $I=2, \phi^{1}=\bar{\phi}$, and $\phi^{2}=0$, we can prove that the same properties shown in Section II.B apply to the general model. This is obvious because, with $\phi^{1}=\bar{\phi}$, agents in C1 do not require a marginal premium on the productive investments. Hence, they are indifferent about the domestic and foreign allocation of the managerial capital. 


\section{Quantitative Analysis}

We now turn to the quantitative implications of the model. The goal is to compare stationary equilibria under financial autarky and perfect capital mobility and to study the transitional dynamics from the former to the latter. Financial globalization is introduced as a once-and-for-all unanticipated regime change. We use a baseline scenario with $I=2$. The first country, C1, is representative of the United States. The second country, C2, aggregates all remaining countries. Later on we add a third country to separate emerging economies from industrial countries other than the United States.

\section{A. Calibration}

We set the population size of $\mathrm{C} 1$ to $\mu^{1}=0.3$ so as to match the U.S. share of world GDP, which is about 30 percent. The stochastic endowment takes two values given by $w=\bar{w}\left(1 \pm \Delta_{w}\right)$, with a symmetric transition probability matrix. The investment shock also takes two values, $z=\bar{z}\left(1 \pm \Delta_{z}\right)$, but it is assumed to be i.i.d. Interpreting $w$ as labor income and $y$ as net capital income, we set $\bar{w}=0.85$, and then we parameterize the production function so that $y=\bar{z} k^{\nu}=0.15$. Because per capita assets are $k=1$, this requires $\bar{z}=0.15$. The share of labor is higher than the typical value of two-thirds because it is in terms of net income, that is, income net of depreciation. The return to scale parameter is set to $\nu=0.75$, implying a share of managerial capital of 0.25 . This generates managerial rents as a fraction of total net income that are relatively small, about 3.75 percent. $^{9}$

For the calibration of the stochastic process of the endowment, we follow recent estimates of the U.S. earnings process and set the persistence probability to 0.95 and $\Delta_{w}=0.6$. These values imply that log earnings have an autocorrelation coefficient of 0.9 and a standard deviation of 0.30 , which are in the ranges of values estimated by Storesletten, Telmer, and Yaron (2004). The variation in the investment shock is set to $\Delta_{z}=2.5$. This implies that the return on productive assets fluctuates between -6 percent and 14 percent. We take this as an approximation to the volatility of firm-level returns. The correlation in productivity shocks across the different projects is set to zero. Therefore, there is wide scope for international diversification of investment risks.

Next we choose the parameters of the financial structure. Several

\footnotetext{
${ }^{9}$ Because the capital income generated by productive activities is 15 percent of total net income and the rents are about 25 percent of capital income, the share of rents in total net income is about $0.15 \times 0.25=0.0375$. This is close to Rotemberg and Woodford's (1995) 3 percent estimate of the profit rate in U.S. firm-level data, although the two estimates are not directly comparable.
} 
indicators, such as those reported in figure 1, suggest that financial markets are significantly different across countries. However, it is difficult to derive a direct mapping from these indicators to the actual values of $\phi^{i}$. Given these difficulties, we take a pragmatic approach. We begin by assigning some values and then we conduct a sensitivity analysis. We start with $\phi^{1}=0.35$ and $\phi^{2}=0$. Thus, contingent claims are partially available in $\mathrm{C} 1$ and unavailable in C2. It is also worth observing that there is a certain degree of equivalence between cross-country differences in $\phi$ 's and differences in the volatility of idiosyncratic shocks. The assumption that $\phi^{1}=0.35$ implies that the equilibrium allocation in C1 is similar to the one that would prevail if contingent claims were not available (i.e., $\phi^{1}=0$ ) but the volatilities of all shocks were 35 percent lower than in C2.

The utility function is constant relative risk aversion (CRRA), with the coefficient of risk aversion set to $\sigma=2$. The intertemporal discount factor is $\beta=0.925$. With this discount factor, the wealth-to-income ratios in the steady state with capital mobility are 2.86 in C1 and 3.45 in C2. The worldwide wealth-to-income ratio is about 3.3. This is higher than the typical number of 3 because our income is net of depreciation. The description of the computational procedure is provided in Appendix D.

\section{B. Results}

Individual policies.-Figure 5 plots the individual decision rules as a function of the net worth $a$, for each value of the endowment $w$, in the steady state with capital mobility. ${ }^{10}$ Three variables are plotted: the value of all contingent claims, $\sum_{s^{\prime}} b\left(s^{\prime}\right) q\left(s, s^{\prime}\right)$; the value of productive assets purchased in C1, $k_{1} P_{1}$; and the value of productive assets purchased in $\mathrm{C} 2, k_{2} P_{2}$.

The net position in contingent claims increases with net worth: it is negative for poorer agents and positive for richer agents. The total position in risky investments also increases with $a$. For the range of $a$ plotted in the figure, all agents choose to buy productive assets in both countries. However, as agents become wealthier, they allocate a larger proportion in C2.

The intuition for this pattern can be described as follows. First, we should observe that, because of the different economic size of the two countries, the equilibrium price of the productive asset in C2 is smaller than in C1. Suppose on the contrary that the two prices were the same.

\footnotetext{
${ }^{10}$ The current realization of the endowment is a state variable because endowment shocks are persistent. The investment shock $z$ can be ignored as a state variable because it is i.i.d.
} 

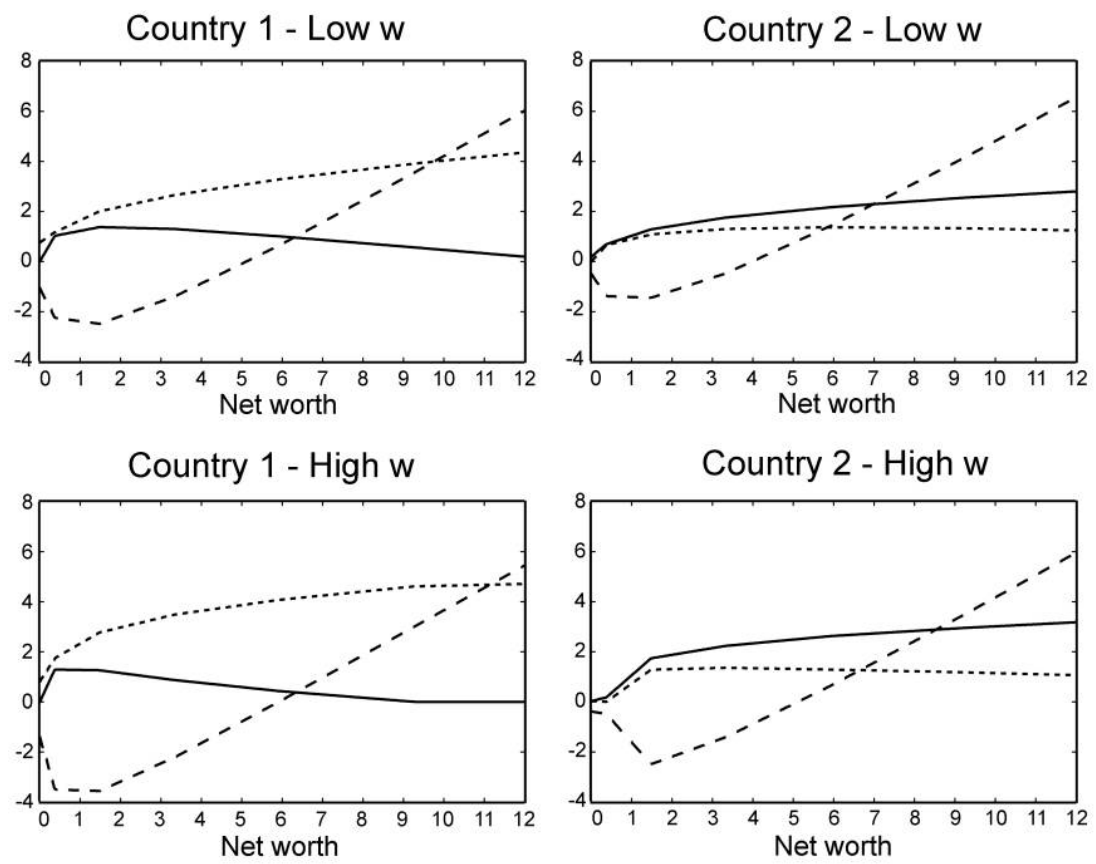

FIG. 5.-Policy rules as functions of net worth

Because investment shocks are uncorrelated across the different projects, when the prices of the productive assets are the same, investors would allocate an equal share of their investments between the domestic and the foreign projects. Therefore, the total demand for the productive asset in $\mathrm{C} 1$ would be exactly equal to the total demand for the productive asset in C2. However, because C2 is larger than C1, the supply in C1 is smaller than in C2. This generates a decline in the price of the productive asset in $\mathrm{C} 2$ relative to the price in $\mathrm{C} 1$. The lower price of the productive asset in C2 implies that the expected return from investing in C2 is higher than in C1. Given CRRA utility, as agents become wealthier, they assign higher weight on returns and less on risk. Therefore, they value less the benefits from diversification and invest more in C2.

Aggregate variables.-Panel A of table 1 reports the equilibrium prices and positions that prevail in the steady-state equilibria under autarky and perfect capital mobility. Under capital mobility, C1 accumulates a net positive position in productive assets but a much larger negative position in contingent claims (bonds).

Country 1's debt and foreign risky asset positions are -89 and 37 percent of its domestic income, respectively. As a result, the NFA position 
TABLE 1

Steady State with and without Capital Mobility

\begin{tabular}{|c|c|c|c|c|}
\hline & \multicolumn{2}{|c|}{ AutARKY } & \multicolumn{2}{|c|}{ Capital Mobility } \\
\hline & $\mathrm{C} 1$ & $\mathrm{C} 2$ & C1 & C2 \\
\hline & \multicolumn{4}{|c|}{ A. Both Shocks } \\
\hline Prices of productive assets & 3.08 & 3.40 & 3.38 & 3.22 \\
\hline Returns on productive assets & 4.80 & 4.30 & 4.41 & 4.58 \\
\hline Standard deviation of returns & 8.11 & 11.76 & 8.83 & 8.95 \\
\hline Interest rate & 3.25 & 2.60 & 3.05 & 3.05 \\
\hline Net foreign asset positions & . & $\ldots$ & -51.39 & 22.12 \\
\hline Productive assets & $\ldots$ & $\ldots$ & 37.41 & -16.10 \\
\hline Bonds & $\ldots$ & $\ldots$ & -88.80 & 38.22 \\
\hline \multirow[t]{2}{*}{ Welfare gains from liberalization } & & & 2.63 & -.27 \\
\hline & \multicolumn{4}{|c|}{ B. Endowment Shocks Only } \\
\hline Prices of productive assets & 2.95 & 3.22 & 3.14 & 3.14 \\
\hline Returns on productive assets & 5.08 & 4.66 & 4.78 & 4.78 \\
\hline Standard deviation of returns & .00 & .00 & .00 & .00 \\
\hline Interest rate & 3.81 & 3.49 & 3.58 & 3.58 \\
\hline Net foreign asset positions & $\ldots$ & $\ldots$ & -38.69 & 16.58 \\
\hline Productive assets & $\ldots$ & $\ldots$ & .00 & .00 \\
\hline Bonds & $\ldots$ & $\ldots$ & -38.69 & 16.58 \\
\hline \multirow[t]{2}{*}{ Welfare gains from liberalization } & & & 1.66 & -.77 \\
\hline & \multicolumn{4}{|c|}{ C. Investment Shocks Only } \\
\hline Prices of productive assets & 1.41 & 1.37 & 1.45 & 1.38 \\
\hline Returns on productive assets & 10.63 & 10.90 & 10.41 & 10.83 \\
\hline Standard deviation of returns & 17.32 & 27.68 & 21.10 & 20.08 \\
\hline Interest rate & 7.35 & 6.58 & 7.33 & 7.33 \\
\hline Net foreign asset positions & $\ldots$ & $\ldots$ & -5.38 & 2.31 \\
\hline Productive assets & $\ldots$ & $\ldots$ & 14.08 & -6.04 \\
\hline Bonds & $\ldots$ & $\ldots$ & -19.46 & 8.35 \\
\hline Welfare gains from liberalization & & & .60 & .20 \\
\hline
\end{tabular}

is negative and quite large, -51 percent of income. Hence, the model is consistent with the data in predicting that the most financially developed country accumulates a substantial negative NFA, chooses a riskier portfolio, and experiences a reduction in the risk-free rate relative to autarky. However, the model overstates the adjustment observed so far in the U.S. economy. As of 2004, the net positions in debt and risky assets were -32 and 9 percent of U.S. GDP, respectively, and the total NFA position was -24 percent of GDP. Note also that the changes in asset prices and interest rates that support these large changes in asset holdings are small.

The model also predicts that financial globalization leads to an increase in the gross holdings of foreign risky assets for all countries (see fig. 5). As Lane and Milesi-Ferretti (2007) noted, this is a salient feature of the financial globalization era (see fig. $2 B$ ). 
A feature of the equilibrium is that the average return from the productive assets is greater than the interest rate. This derives from two mechanisms. First, because of decreasing returns, there is a surplus that compensates managerial capital. Therefore, even if the marginal return on the productive asset is equal to the interest rate, total production is bigger than the opportunity cost of the investment. ${ }^{11}$ The second mechanism relates to the investment risk. Because of this risk, investors require a marginal premium over the interest rate that further increases the average return.

Consider now the special versions of the model with only endowment or investment shocks. Panels B and C of table 1 report the steady-state values of some key variables in these cases. With endowment shocks only (panel B), the model can produce a large negative NFA position in C1 (of roughly -38 percent of domestic income). However, with only endowment shocks, the model cannot explain the observed shift in the composition of the portfolios of foreign assets. By contrast, the setup with only investment shocks (panel C) does produce a portfolio for C1 characterized by a negative debt position and a positive position in risky assets. The total NFA position, however, is not very large. The reason is that as $\mathrm{C} 1$ takes a greater position in risky assets, it faces greater risk inducing higher savings.

In summary, these results show that by combining endowment and investment shocks, we can capture both features of the U.S. international asset position: large net foreign liabilities and a portfolio composition tilted toward high-return assets.

Transition after liberalization.-Figure 6 plots the transitional dynamics from autarky to full financial integration for several aggregate variables. The top left panel shows that the decline in net foreign assets in $\mathrm{C} 1$ is a slow, gradual process that takes about 30 years. The current account drops to a deficit of almost 4 percent of domestic income on impact and remains in deficit for many periods until it converges to zero in about 50 years.

The deterioration of the current account in $\mathrm{Cl}$ is not as gradual as in the U.S. data. In our results, however, the pattern of a large initial deficit followed by gradual recovery is a consequence of the assumption that capital markets are fully integrated overnight. In reality, financial integration has been a gradual process (see fig. 2). With gradual integration the model would have displayed current account dynamics more in line with the U.S. data.

Figure 6 also plots the dynamics for the components of NFA and the current account. Immediately after financial integration, C1 purchases

\footnotetext{
${ }^{11}$ Decreasing returns are important for this feature of the model and for supporting a well-defined portfolio choice.
} 

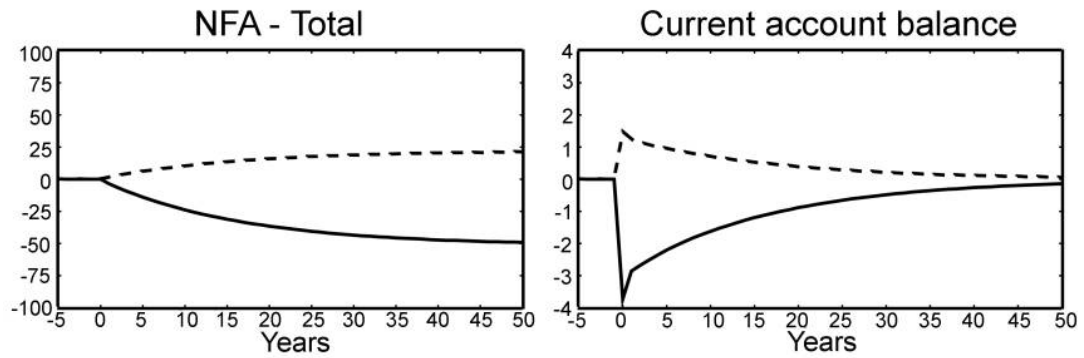

NFA - Productive assets

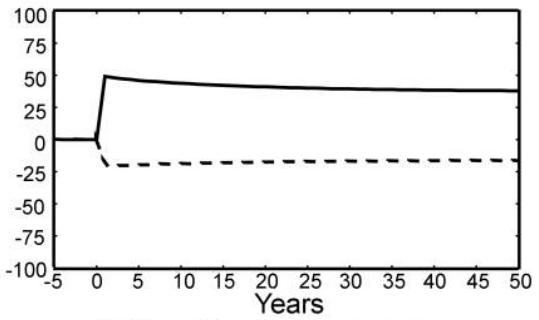

Net exports

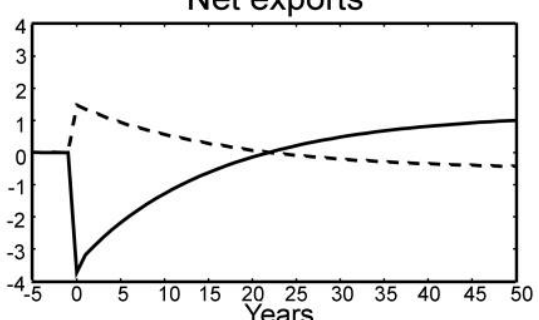

NFA - Contingent claims

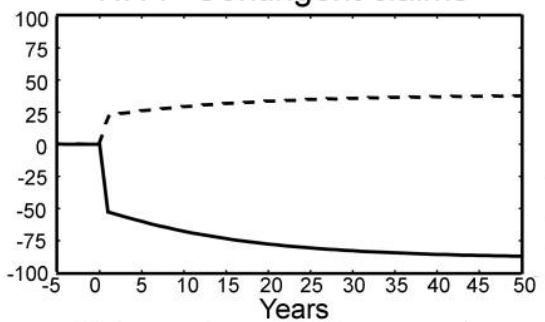

Net factor payments

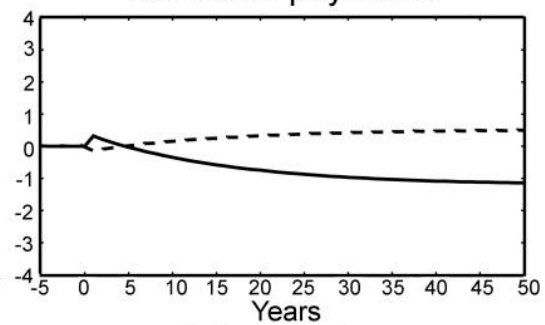

Prices of productive assets

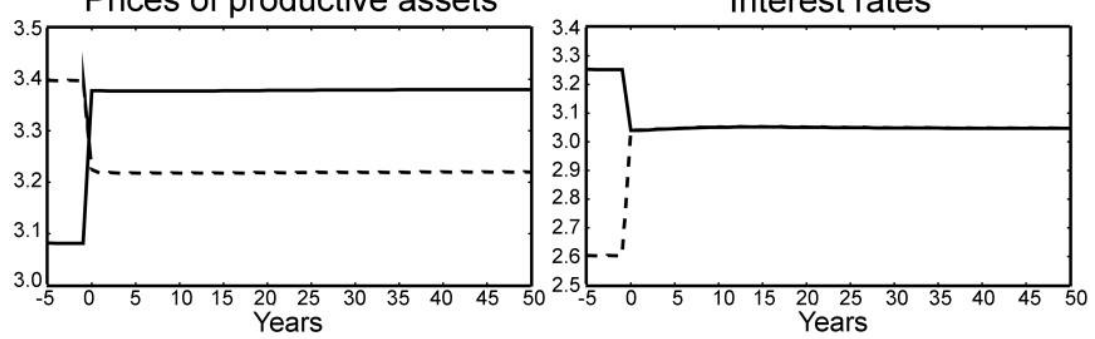

FIG. 6.-Transition dynamics after capital markets liberalization

a large quantity of foreign productive assets financed with foreign debt. Despite the negative NFA position, C1 receives initially positive net factor payments from abroad as a result of the higher return on the productive assets. These payments, however, are more than compensated by negative net exports, and thus the country experiences current account deficits until it reaches the new steady state. 

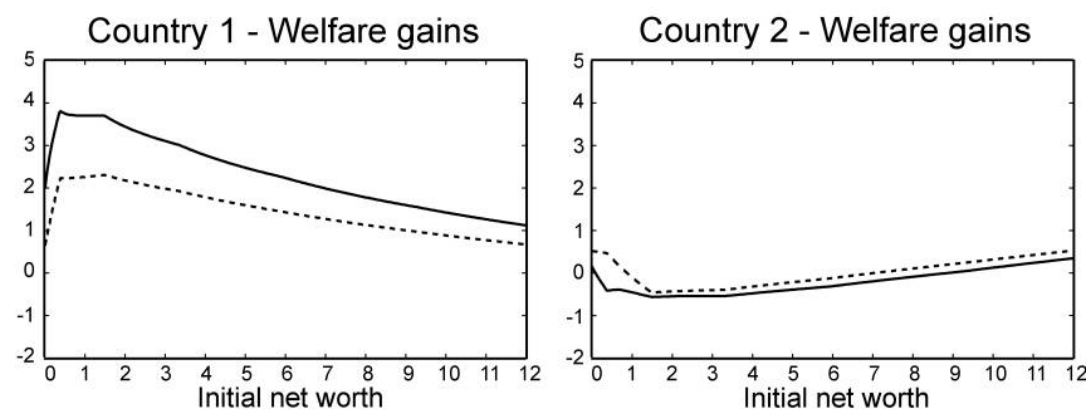

Country 1 - Distribution

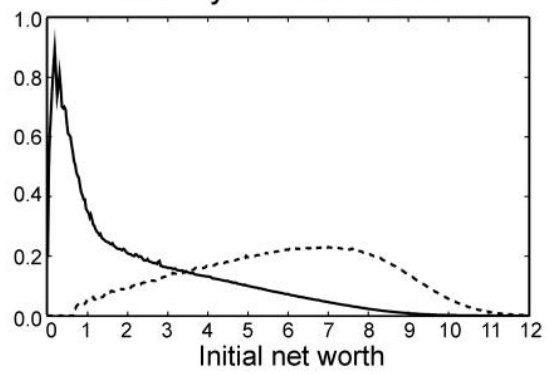

Country 2 - Distribution

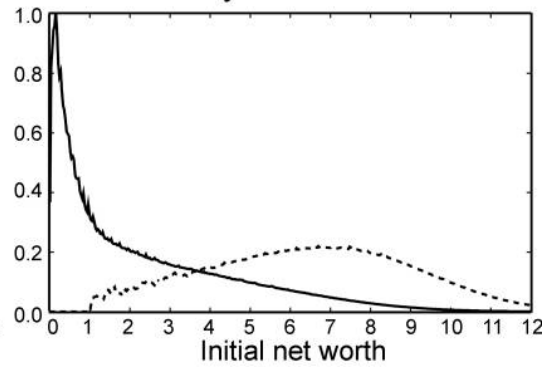

FIG. 7.-Welfare effects of financial integration

Normative implications.-We examine next the normative implications of the model. We are interested in answering two questions. First, is financial integration welfare enhancing for the participating countries? Second, how are the welfare effects distributed among the population of each country?

The model features three mechanisms by which financial integration can affect welfare. First, by investing in both countries, households can diversify the investment risks. Second, countries can specialize in more (C1) or less (C2) risky activities. Third, financial integration can benefit C1 citizens and hurt C2 residents because its effects on asset prices cause capital gains and losses and changes in the rate of interest (see fig. 6).

Figure 7 plots the welfare gains (or losses if negative) from financial integration as a function of individual net worth, $a$, and endowment, $w$, when the reform is introduced. These welfare gains are computed as the percentage increase in consumption in the autarky steady state that makes each individual agent indifferent between remaining in autarky and shifting to the regime with financial integration. The figure also shows, for each country, the distribution of agents over net worth in the autarky steady state. This is the initial distribution when the international capital markets are liberalized.

In $\mathrm{C} 1$ all agents gain from liberalization, and the gains are especially 
large for agents with lower initial wealth. For these agents, the gains derive from all the reasons described above, and in particular from the reduction in the interest rate. As shown in the bottom-left chart of figure 7 , poorer agents are initially net borrowers, and therefore, they benefit from a reduction in the interest rate. Richer agents, instead, are net lenders, and they are hurt by lower interest rates.

The increase in the interest rate relative to autarky in C2 affects negatively the welfare of its poorer residents because they are net borrowers. These effects are large, and the global effect is a reduction in their welfare. Richer residents in C2 experience overall an increase in welfare.

We aggregate the individual welfare effects using a social welfare function that weights each agent's utility equally. The aggregate welfare effects are measured by the same percentage increase in the consumption of all agents in the autarky steady state that makes the value of the aggregate welfare equal to the value in the regime with financial integration. We find that $\mathrm{C} 1$ gains about 2.6 percent of aggregate consumption and C2 loses 0.27 percent.

\section{Sensitivity to the Cross-Country Correlation of Shocks}

Table 2 reports the steady-state statistics under autarky and financial integration for correlated cross-country investment shocks. Panel A assumes a correlation of 0.5 , which reduces the gains from international diversification of investment, and in panel B the correlation is one, which completely eliminates such gains. ${ }^{12}$

While the table shows a reduction in the absolute value of the NFA position of $\mathrm{C} 1$, such a position is still very large. The increase in the correlation of shocks also increases the two components of the NFA position in absolute value, since the gains of specialization are now larger.

The ability to diversify the investment risk is important for welfare. As we increase the cross-country correlation of shocks, and hence reduce the ability to diversify the investment risk, the welfare gains from international capital market integration become smaller. As a result, C1's gain falls and C2's loss rises.

\section{Residence- versus Source-Based Enforcement}

The analysis conducted so far was based on the assumption that the enforcement parameter $\phi$ is residence based (i.e., it depends on the

\footnotetext{
${ }^{12}$ International output correlations are typically in the $0.4-0.7$ range, but the relevant correlations to match with the model should be measured at the level of individual incomes, not aggregate output.
} 
TABLE 2

Sensitivity to the Cross-Country Correlation of Shocks

\begin{tabular}{|c|c|c|c|c|}
\hline & \multicolumn{2}{|c|}{ AutARKy } & \multicolumn{2}{|c|}{ Capital Mobility } \\
\hline & C1 & $\mathrm{C} 2$ & C1 & $\mathrm{C} 2$ \\
\hline & \multicolumn{4}{|c|}{$\begin{array}{l}\text { A. Shocks Are Partially Correlated (Correla- } \\
\text { tion }=.5 \text { ) }\end{array}$} \\
\hline Prices of productive assets & 3.08 & 3.40 & 3.34 & 3.26 \\
\hline Returns on productive assets & 4.81 & 4.30 & 4.32 & 4.57 \\
\hline Standard deviation of returns & 8.11 & 11.76 & 9.44 & 10.78 \\
\hline Interest rate & 3.25 & 2.60 & 2.92 & 2.92 \\
\hline Net foreign asset positions & $\ldots$ & $\ldots$ & -47.69 & 20.54 \\
\hline Productive assets & & & 60.29 & -25.97 \\
\hline Bonds & & & -107.98 & 46.50 \\
\hline \multirow[t]{2}{*}{ Welfare gains from liberalization } & & & 2.18 & -.49 \\
\hline & \multicolumn{4}{|c|}{$\begin{array}{l}\text { B. Shocks Are Perfectly Correlated (Correla- } \\
\text { tion }=1)\end{array}$} \\
\hline Prices of productive assets & 3.08 & 3.40 & 3.28 & 3.28 \\
\hline Returns on productive assets & 4.81 & 4.30 & 4.26 & 4.59 \\
\hline Standard deviation of returns & 8.11 & 11.76 & 7.27 & 12.50 \\
\hline Interest rate & 3.25 & 2.48 & 2.83 & 2.83 \\
\hline Net foreign asset positions & $\ldots$ & $\ldots$ & -43.67 & 18.52 \\
\hline Productive assets & t. & $\ldots$ & 82.36 & -34.92 \\
\hline Bonds & & & -126.03 & 53.44 \\
\hline Welfare gains from liberalization & & & 1.77 & -.60 \\
\hline
\end{tabular}

country of residence of the agents, independently of whether their incomes are generated at home or abroad) rather than source based (i.e., it depends on where the incomes are generated). Such an assumption is based on the view that the ability to verify diversion requires the verification of individual consumption, which uses the resident's country's legal system. We now explore environments with alternative assumptions about the residence or source nature of the enforcement of contracts. We consider four alternative scenarios, with results reported in table 3. In all the experiments, we use the same values of $\phi$ as in the baseline calibration, that is, $\phi^{1}=0.35$ and $\phi^{2}=0$.

In panel A the enforcement of contracts for residents of C1 remains as in the baseline model; that is, $\phi^{1}$ applies to both foreign and domestic incomes. Residents of C2 are bound by $\phi^{2}$ for incomes earned at home and by $\phi^{1}$ for incomes earned abroad. Therefore, C2 residents use the legal system of $\mathrm{C} 1$ for incomes earned abroad. The enforcement constraint for C2 becomes

$$
\begin{aligned}
a\left(s_{n}\right)-a\left(s_{1}\right) \geq & \left(1-\phi^{2}\right) \cdot\left[w^{n}-w^{1}+\left(z_{2}^{n}-z_{2}^{1}\right) A_{2, t}^{1-\nu} k_{2, t}^{\nu}\right] \\
& +\left(1-\phi^{1}\right)\left(z_{1}^{n}-z_{1}^{1}\right) A_{1, t}^{1-\nu} k_{1, t}^{\nu} .
\end{aligned}
$$

Panel B reverses the situation: C1 residents can use their country's 
TABLE 3

Sensitivity to Alternative Assumptions about the Nature of $\phi$

\begin{tabular}{|c|c|c|c|c|}
\hline & \multicolumn{2}{|c|}{ AUtARKY } & \multicolumn{2}{|c|}{ Capital Mobility } \\
\hline & $\mathrm{C} 1$ & $\mathrm{C} 2$ & $\mathrm{C} 1$ & $\mathrm{C} 2$ \\
\hline & \multicolumn{4}{|c|}{ A. Source Based Only for Residents of C2 } \\
\hline Prices of productive assets & 3.08 & 3.40 & 3.47 & 3.20 \\
\hline Returns on productive assets & 4.81 & 4.30 & 4.43 & 4.54 \\
\hline Standard deviation of returns & 8.11 & 11.76 & 7.44 & 9.34 \\
\hline Interest rate & 3.25 & 2.60 & 2.97 & 2.97 \\
\hline Net foreign asset positions & 年 & $\ldots$ & -54.98 & 23.67 \\
\hline Productive assets & & $\ldots$ & 4.36 & -1.88 \\
\hline Bonds & & 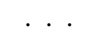 & -59.34 & 25.55 \\
\hline \multirow[t]{2}{*}{ Welfare gains from liberalization } & & & 2.67 & -.38 \\
\hline & \multicolumn{4}{|c|}{ B. Source Based Only for Residents of C1 } \\
\hline Prices of productive assets & 3.08 & 3.40 & 3.43 & 3.19 \\
\hline Returns on productive assets & 4.81 & 4.30 & 4.52 & 4.57 \\
\hline Standard deviation of returns & 8.11 & 11.76 & 6.57 & 7.75 \\
\hline Interest rate & 3.25 & 2.60 & 3.10 & 3.10 \\
\hline Net foreign asset positions & $\ldots$ & $\ldots$ & -51.16 & 22.07 \\
\hline Productive assets & $\ldots$ & $\ldots$ & 10.41 & -4.49 \\
\hline Bonds & & $\ldots$ & -61.57 & 26.56 \\
\hline \multirow[t]{2}{*}{ Welfare gains from liberalization } & & & 2.87 & -.05 \\
\hline & \multicolumn{4}{|c|}{$\begin{array}{l}\text { C. Partially Source Based for Residents of } \\
\text { Both Countries }\end{array}$} \\
\hline Prices of productive assets & 3.08 & 3.40 & 3.45 & 3.20 \\
\hline Returns on productive assets & 4.81 & 4.30 & 4.48 & 4.55 \\
\hline Standard deviation of returns & 8.11 & 11.76 & 7.26 & 8.58 \\
\hline Interest rate & 3.25 & 2.60 & 3.03 & 3.03 \\
\hline Net foreign asset positions & $\ldots$ & $\ldots$ & -52.21 & 22.50 \\
\hline Productive assets & & $\ldots$ & 5.07 & -2.18 \\
\hline Bonds & & 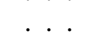 & -57.28 & 24.68 \\
\hline \multirow[t]{2}{*}{ Welfare gains from liberalization } & & & 2.71 & -.22 \\
\hline & \multicolumn{4}{|c|}{$\begin{array}{l}\text { D. Source Based for Residents of Both } \\
\text { Countries }\end{array}$} \\
\hline Prices of productive assets & 3.08 & 3.40 & 3.50 & 3.17 \\
\hline Returns on productive assets & 4.81 & 4.30 & 4.54 & 4.53 \\
\hline Standard deviation of returns & 8.11 & 11.76 & 5.88 & 8.37 \\
\hline Interest rate & 3.25 & 2.60 & 3.02 & 3.02 \\
\hline Net foreign asset positions & $\ldots$ & $\ldots$ & -54.02 & 23.31 \\
\hline Productive assets & & $\ldots$ & -22.13 & 9.55 \\
\hline Bonds & & & -31.89 & 13.76 \\
\hline Welfare gains from liberalization & & & 2.80 & -.11 \\
\hline
\end{tabular}

NotE.-See table 1. 
legal system for activities carried out domestically, but they have to use the legal system of C2 for incomes earned abroad. Residents of C2 use their own legal system for all economic activity. Panel C considers the situation in which the enforcement is in part source based and in part residence based for the residents of both countries. More specifically, the foreign incomes earned by the residents of both countries are enforced according to $\tilde{\phi}=\left(\phi^{1}+\phi^{2}\right) / 2$. This implies that agents in C1 get less insurance on foreign earned incomes than on domestic incomes but still greater than the insurance available to residents of C2. Similarly, C2 agents can get better insurance on incomes earned abroad but not as good as the $\mathrm{C} 1$ residents. Finally, panel D considers the case in which enforcement is fully source based in both countries.

Panels A-C of table 3 show that C1 accumulates a large negative NFA asset position and keeps a positive position in productive assets. Therefore, even with partial residence-based enforcement, C1 continues to have a positive position in productive assets together with a negative NFA. In panel D, where enforcement is fully source based, however, the net position in productive assets becomes negative.

\section{Alternative Forms of Financial Development: Industrialized versus Emerging Economies}

The only form of financial heterogeneity considered so far derives from cross-country differences in the parameter $\phi$. In this section we consider a second form of financial heterogeneity captured by differences in the liability constraint (condition [4]). This constraint can be written more generally as $a\left(s_{n}\right) \geq \underline{a}^{i}$, where $\underline{a}^{i}$ is a parameter that differs across countries. Hence, financial development is now captured by differences in $\phi^{i}$ and $\underline{a}^{i}$.

By adding a third country and characterizing financial heterogeneity in terms of both $\underline{a}$ and $\phi$, we can replicate the main features of the composition of foreign assets observed separately for the United States, other industrialized countries, and emerging economies. Before adding a third country, we examine how the properties of the model change with different $\phi$ 's and/or $\underline{a}$ 's in the two-country setup.

Table 4 compares steady states under autarky and financial integration for different combinations of $\phi$ and $\underline{a}$. Panel A assumes that both countries have the same $\phi$, but $\mathrm{C} 1$ is still more financially developed because it has a lower value of $\underline{a}$. Panel B allows C1 to be more financially developed in both dimensions, higher $\phi$ and lower $\underline{a}$.

Independently of whether financial heterogeneity derives from differences in $\phi$ or $\underline{a}, \mathrm{C} 1$ ends up with a large negative NFA position. There are important differences, though, in the composition of NFA. In panel A, where the differences are only in $\underline{a}, \mathrm{C} 1$ also has negative net holdings 
TABLE 4

Steady State With Heterogeneity in $\phi$ And $\underline{a}$

\begin{tabular}{|c|c|c|c|c|}
\hline & \multicolumn{2}{|c|}{ AutARKY } & \multicolumn{2}{|c|}{ Capital Mobility } \\
\hline & C1 & C2 & $\mathrm{C} 1$ & C2 \\
\hline & \multicolumn{4}{|c|}{$\begin{array}{l}\text { A. Differences in } \underline{a} \text { Only: } \underline{a}^{1}=-1, \underline{a}^{2}=0 \\
\qquad \phi^{1}=\phi^{2}=.35\end{array}$} \\
\hline Prices of productive assets & 2.96 & 3.40 & 3.39 & 3.16 \\
\hline Returns on productive assets & 4.94 & 4.30 & 4.56 & 4.56 \\
\hline Standard deviation of returns & 13.38 & 11.76 & 9.04 & 9.15 \\
\hline Interest rate & 3.02 & 2.60 & 3.00 & 2.85 \\
\hline Net foreign asset positions & $\ldots$ & $\ldots$ & -65.81 & 28.31 \\
\hline Productive assets & $\ldots$ & & -13.96 & 6.01 \\
\hline Bonds & $\ldots$ & & -51.85 & 22.30 \\
\hline \multirow[t]{2}{*}{ Welfare gains from liberalization } & & & 2.99 & -.46 \\
\hline & \multicolumn{4}{|c|}{$\begin{array}{l}\text { B. Differences in Both: } \underline{a}^{1}=-1, \underline{a}^{2}=0 \text {, } \\
\qquad \phi^{1}=.35, \phi^{2}=0\end{array}$} \\
\hline Prices of productive assets & 2.74 & 3.40 & 3.25 & 3.09 \\
\hline Returns on productive assets & 5.42 & 4.30 & 4.59 & 4.77 \\
\hline Standard deviation of returns & 9.09 & 11.76 & 9.19 & 9.30 \\
\hline Interest rate & 3.68 & 2.60 & 3.18 & 3.18 \\
\hline Net foreign asset positions & & . & -105.25 & 45.30 \\
\hline Productive assets & & & 35.89 & -15.45 \\
\hline Bonds & & & -141.14 & 60.75 \\
\hline Welfare gains from liberalization & & & 4.50 & -.89 \\
\hline
\end{tabular}

of the productive assets (because of the lower prices of foreign assets). In panel $\mathrm{B}$, with differences in $\phi, \mathrm{C} 1$ takes a positive net position in productive assets.

These results indicate that cross-country differences in $\phi$ are needed in order to generate a situation in which the United States accumulates a negative NFA position and a positive position in high-return assets. Differences in $\underline{a}$ cannot yield this outcome by themselves because lower values of $\underline{a}$ decrease the propensity to save but do not change the propensity to take investment risks.

\section{A. A Three-Country Model}

It is reasonable to argue that the United States and other industrial countries do not differ much in the institutional and technological environment that allows for the insurance of income risks. Yet, the evidence reviewed in the introduction shows that the development of nonbank financial intermediation has progressed more in the United States, and this is also consistent with the higher ratio of domestic credit to the private sector to GDP of the United States compared to other indus- 
trialized countries. ${ }^{13}$ This suggests that the differences in financial markets between the United States and other industrialized countries are more likely to derive from differences in $\underline{a}$ than in $\phi$. However, the financial market differences between the United States and emerging economies, where the ability to insure risks is much weaker and the volume of credit is much lower, are likely to derive from both $\underline{a}$ and $\phi$.

To capture these ideas, we extend the model to study the implications of financial integration among three countries or regions: the United States (C1), other developed countries (C2), and emerging economies (C3). On the basis of the above discussion, we assume that C1 differs from C2 only in $\underline{a}$ whereas it differs from C3 in both $\phi$ and $\underline{a}$. We set $\phi=(0.5,0.5,0)$ and $\underline{a}=(-1,0,0) .^{14}$

We capture the differences in the economic size of the three countries by setting relative population sizes to $\mu=(0.3,0.5,0.2)$. As explained earlier, by setting the population share of emerging economies to 0.2 , we capture the fact that these economies contribute about 20 percent of the world GDP.

Except for the parameters of the financial structure and relative population, all other parameters are as in the baseline parameterization. The key steady-state variables are reported in table 5 .

The foreign asset structure of the three countries is broadly consistent with the asset structure shown in figure 3 for the United States, other industrialized countries, and emerging economies. In particular, under financial integration the other industrialized countries (C2) have a position in risky assets very similar to that of the United States (C1). However, the NFA position is significantly smaller compared to C1. Yet, C3, which represents the emerging economies, has a positive NFA position and a negative net position in risky assets. The large increase in net

${ }^{13}$ According to the World Bank's World Development Indicators, in 2004 domestic credit to the private sector was 191 percent of GDP in the United States vs. 136 percent for the other Group of Seven countries and 122 percent for the average of OECD countries excluding the United States.

${ }^{14}$ While it is difficult to obtain direct evidence about the availability of insurance against income risks, there are some studies suggesting that insurance is smaller in emerging economies than in developed countries, even if only for regional instead of individual shocks. For example, $\mathrm{Xu}$ (2008) finds that there is less consumption risk sharing across Chinese provinces than across U.S. states and Canadian provinces and concludes that "Chinese households would be willing to pay dearly to insure their consumption against idiosyncratic shocks" (340). In the same vein, Kim, Kim, and Wang (2006) estimate the degree of consumption risk sharing among 10 East Asian countries and find that about 80 percent of the cross-sectional variation of GDP is not smoothed within the region. Compared to the OECD countries, the degree of risk sharing achieved is significantly lower and the potential gains are larger. An implication of the lower $\phi$ in emerging economies under autarky is that the risk-free interest rate is lower. In this regard, Bailey (1994) reports that in the early stages of China's financial opening, there were A shares targeted at Chinese savers and B shares for non-Chinese. Type B shares were sold at a large discount, indicating that the internal rate of return was much lower for Chinese households. 
TABLE 5

Steady State in the Three-Country Economy

\begin{tabular}{|c|c|c|c|c|c|c|}
\hline & \multicolumn{3}{|c|}{ AutARKy } & \multicolumn{3}{|c|}{ CAPITAL MoBility } \\
\hline & C1 & C2 & C3 & C1 & C2 & C3 \\
\hline Prices of productive assets & 2.65 & 2.95 & 3.40 & 2.86 & 2.84 & 2.88 \\
\hline $\begin{array}{l}\text { Returns on productive } \\
\text { assets }\end{array}$ & 5.63 & 5.05 & 4.30 & 5.16 & 5.17 & 5.36 \\
\hline $\begin{array}{l}\text { Standard deviation of } \\
\text { returns }\end{array}$ & 7.17 & 6.44 & 11.76 & 4.20 & 4.23 & 8.17 \\
\hline Interest rate & 3.96 & 3.53 & 2.60 & 3.73 & 3.73 & 3.63 \\
\hline Net foreign asset positions & . & . & $\ldots$ & -72.92 & 2.88 & 103.15 \\
\hline Productive assets & . & $\ldots$ & $\ldots$ & 9.32 & 9.51 & -38.56 \\
\hline Bonds & . & . & $\ldots$ & -82.24 & -6.63 & 141.72 \\
\hline
\end{tabular}

bond holdings suggests that if the foreign bonds are held by official institutions, the model can explain the recent surge in the foreign reserves of emerging economies.

\section{B. Adding Differences in Growth and Income Volatility}

Our model is robust in predicting that, as long as there are differences in domestic financial markets between industrialized and emerging economies, financial globalization may result in the latter becoming net suppliers of funds to the former. In making this case we abstracted from two other important dimensions in which emerging economies differ from industrialized countries: growth rates and income volatility.

Growth differences can be important because, as predicted by the standard neoclassical open-economy model, countries experiencing faster growth (emerging economies) should borrow from slow-growing countries (industrialized economies). However, recent trends seem to suggest the opposite (see, e.g., Gourinchas and Jeanne 2007).

The prediction of the neoclassical model about the flow of capital for fast-growing countries is an unavoidable consequence of CRRA preferences. If we ignore uncertainty, the Euler equation reads as $\left(c_{t+1} / c_{t}\right)^{\sigma}=\beta\left(1+r_{t}\right)$. Faster growth in consumption before financial integration implies a higher value of the left-hand-side term of the Euler equation, which in turn implies a higher interest rate. As a result, when countries experiencing faster than average growth become financially integrated, their interest rates converge to a lower "world" interest rate and save less.

If we abstract from heterogeneity in domestic financial markets, our model shares the same features of the neoclassical model. However, once we introduce financial market differences, we have two opposing 
effects. The higher growth of emerging economies induces these countries to save less whereas the lower development of their financial markets induces higher savings. So ultimately, which mechanism dominates depends on the relative importance of "growth differences" versus "financial differences."

In addition to growth, another important difference between industrialized and emerging economies is that the latter are typically countries that are experiencing significant structural changes, which are often associated with greater uncertainty at the individual level. ${ }^{15}$ Therefore, if we want to capture the differences between industrialized and emerging economies that are relevant for savings, we should allow for three sources of heterogeneity: financial market development, economic growth, and income volatility.

We add heterogeneity in growth and income volatility to the threecountry model examined above. An easy way to capture differences in growth rates is to assume that countries have different discount rates. If $\beta$ is the discount factor for industrialized countries and the growth rate differential between emerging and industrialized countries is $1+g$, then the discount factor of emerging countries is $\tilde{\beta}=\beta /(1+g)^{\sigma}$. With an annual growth differential of 3.5 percent and given the baseline parameterization $\beta=0.925$ and $\sigma=2$, the discount factor for C3 is $\tilde{\beta}=$ $0.925 / 1.035^{2}=0.863$. In this case, if $\mathrm{C} 1$ and $\mathrm{C} 2$ grow at about 2 percent per year, emerging countries (C3) grow at 5.5 percent per year. To account for the higher uncertainty faced by agents in emerging economies, we assume that the standard deviations of endowment and investment shocks in $\mathrm{C} 3$ are 50 percent higher than in $\mathrm{C} 1$ and C2.

Table 6 reports the steady-state statistics. Even if C3 grows faster than the other two countries, the combination of greater uncertainty and lower financial development induces agents in C3 to save more. As a result, C3 accumulates a positive NFA position, and the composition of its portfolio is tilted toward less risky and less profitable assets. In short, our key findings seem robust to the introduction of differences in growth and income volatility.

\section{Conclusion}

This paper shows that international financial integration can lead to large and persistent global imbalances when countries differ in the de-

${ }^{15}$ An indicator of this is that inequality tends to increase during phases of rapid growth. See Khan and Riskin (2001) and Naughton (2007). Also, several emerging economies have experienced sudden stops after entering the global financial markets. The role played by differences in the volatility of risk for the accumulation of foreign assets or reserves has also been explored in Carroll and Jeanne (2008) and Durdu, Mendoza, and Terrones (2009). 
TABLE 6

Steady State in the Three-Country Economy with Heterogeneity in Financial Development, Growth, and Income Volatility

\begin{tabular}{|c|c|c|c|c|c|c|}
\hline & \multicolumn{3}{|c|}{ AUTARKY } & \multicolumn{3}{|c|}{ Capital Mobility } \\
\hline & C1 & $\mathrm{C} 2$ & C3 & C1 & $\mathrm{C} 2$ & C3 \\
\hline Prices of productive assets & 2.65 & 2.95 & 3.84 & 2.85 & 2.82 & 2.87 \\
\hline $\begin{array}{l}\text { Returns on productive } \\
\text { assets }\end{array}$ & 5.63 & 5.05 & 3.60 & 5.10 & 5.10 & 5.81 \\
\hline $\begin{array}{l}\text { Standard deviation of } \\
\text { returns }\end{array}$ & 7.17 & 6.44 & 19.51 & 4.14 & 4.16 & 14.13 \\
\hline Interest rate & 3.96 & 3.53 & 1.24 & 3.68 & 3.68 & 3.68 \\
\hline Net foreign asset positions & . . & $\ldots$ & $\ldots$ & -76.89 & -.23 & 117.07 \\
\hline Productive assets & . . & $\ldots$ & 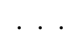 & 29.68 & 29.54 & -120.70 \\
\hline Bonds & 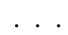 & $\ldots$ & . & -106.57 & -29.77 & 237.77 \\
\hline
\end{tabular}

gree of domestic financial development. Financial integration induces countries with deeper financial markets to reduce savings and accumulate a large stock of net foreign liabilities in a long and gradual process. Financial heterogeneity also affects the composition of the portfolio of net foreign assets. Countries with deeper financial markets borrow heavily from abroad and invest in high-return foreign risky assets. These patterns are consistent with the features of the global external imbalances observed since the beginning of the 1980s. The model can generate these patterns as the outcome of financial integration in a world in which the development of domestic financial markets is the only source of cross-country heterogeneity.

The main implications of our analysis proved to be robust to $(a)$ introducing alternative forms of financial development, $(b)$ allowing for international diversification of individual risks, $(c)$ considering residence- or source-based enforcement of contracts, and $(d)$ combining domestic financial heterogeneity with relatively large differences in growth rates and idiosyncratic income volatility. Thus, we conclude that financial globalization among countries with heterogeneous domestic financial markets can be an important factor for explaining the large external imbalances that have emerged across the United States, other industrial countries, and emerging economies.

Appendix A

Data

Emerging economies.-Argentina, Brazil, Chile, China, Colombia, Czech Republic, Egypt, Hong Kong, Hungary, India, Indonesia, Israel, Jordan, Korea, Malaysia, Morocco, Pakistan, Peru, Philippines, Poland, Russia, Saudi Arabia, Singapore, South Africa, Thailand, and Turkey. 
Financial development indicators.-The IMF (2006) proposes an index of financial market development for industrial countries. The index combines information from three core subindexes: an index of traditional bank intermediation, an index of new financial intermediation (i.e., intermediation through direct market instruments, such as asset-backed securities and derivatives, and/or nonbank intermediaries, such as hedge funds), and an index of general characteristics of financial markets (stock market turnover, investor protection, bond market capitalization, etc.). Countries with a higher index undertake a larger volume of financial intermediation through direct market instruments and are viewed as having attained a higher degree of financial development.

Abiad et al. (2008) constructed an 82-country database of financial reforms for both industrialized and emerging economies over the period 1973-2002, with seven dimensions of financial sector policies: (1) credit controls and high reserve requirements, (2) interest rate controls, (3) entry barriers, (4) state ownership in the banking sector, (5) capital account restrictions, (6) prudential regulations and supervision of the banking sector, and (7) securities market policies. The financial liberalization index in figure $1 B$ is the average of those indicators.

Financial globalization index.-Chinn and Ito (2005) compiled an index of the degree of capital account openness for 163 countries from 1970 to 2004. The index is based on binary dummy variables that codify the restrictions on crossborder financial transactions reported in the IMF's Annual Report on Exchange Arrangements and Exchange Restrictions. The dummy variables reflect the four major categories of restrictions: multiple exchange rates, restrictions on current account transactions, restrictions on capital account transactions, and requirements for the surrender of export proceeds. The index is the first standardized principal component of these four variables, and it takes higher values for countries that are more open to cross-border capital transactions. The indices for country groups are computed by averaging the individual country indices, weighted by GDP.

Foreign asset positions.-Lane and Milesi-Ferretti (2007) have constructed data on gross and net foreign assets and liabilities, for different instruments, over the period 1970-2004. The NFA positions are calculated by aggregating the different assets and liabilities.

\section{Appendix B}

\section{Set of Feasible Contingent Claims}

Suppose that agents have the ability to divert part of their income. Diversion is observable but not verifiable in a legal sense. If an agent diverts $x$, he or she retains $(1-\phi) x$ and the remaining part, $\phi x$, is lost. We allow $\phi$ to be greater than one. This can be interpreted as a fine or additional punishment. A similar assumption is made in Castro, Clementi, and MacDonald (2004) in an environment with information asymmetry.

Contracts are signed with financial intermediaries in a competitive environment. Financial contracts are not exclusive, meaning that agents can always switch to another intermediary from one period to the other. The set of state- 
contingent claims that an intermediary is willing to offer must be incentive compatible.

Let $V_{t}(s, a)$ be the value function for an agent with current realization of shocks, $s=(w, z)$, and current net worth, $a$. The net worth is before consumption. After the contingent claims $b\left(s_{n}\right)$ are chosen, the next period value is $V_{t}\left(s_{n}, a\left(s_{n}\right)\right)$, where $a\left(s_{n}\right)=w_{n}+z_{n} k^{\nu}+k P_{t+1}+b\left(s_{n}\right)$. In case of diversion, the agent would claim that the realizations of the endowment and productivity were the lowest levels, $s_{1}=\left(w_{1}, z_{1}\right)$, and divert $w_{n}-w_{1}+\left(z_{n}-z_{1}\right) k^{\nu}$. In this process the agent retains $(1-\phi)\left[w_{n}-w_{1}+\left(z_{n}-z_{1}\right) k^{\nu}\right]$ and receives $b\left(s_{1}\right)$. Therefore, the net worth after diversion is

$$
\begin{gathered}
w_{1}+z_{1} k^{\nu}+(1-\phi) \cdot\left[w_{n}-w_{1}+\left(z_{n}-z_{1}\right) k^{\nu}\right]+k P_{t+1}+b\left(s_{1}\right)= \\
a\left(s_{1}\right)+(1-\phi) \cdot\left[w_{n}-w_{1}+\left(z_{n}-z_{1}\right) k^{\nu}\right]
\end{gathered}
$$

and the value of diversion is

$$
V_{t}\left(s_{n}, a\left(s_{1}\right)+(1-\phi) \cdot\left[w_{n}-w_{1}+\left(z_{n}-z_{1}\right) k^{\nu}\right]\right) .
$$

Incentive compatibility requires that the following holds for all $n=1, \ldots, N$ :

$$
V_{t}\left(s_{n}, a\left(s_{n}\right)\right) \geq V_{t}\left(s_{n}, a\left(s_{1}\right)+(1-\phi) \cdot\left[w_{n}-w_{1}+\left(z_{n}-z_{1}\right) k^{\nu}\right]\right) .
$$

It is important to emphasize that the financial intermediary can tell whether the agent is diverting, but there is no court that can verify this and force the repayment of the diverted funds. Compared to the standard model with information asymmetries, this assumption is convenient because it simplifies the contracting problem when shocks are persistent. Also convenient is the assumption that financial contracts are not exclusive and agents can switch to other intermediaries from one period to the other without a cost. This further limits the punishments available to the current intermediary. Also notice that, although the new level of wealth after diversion is verifiable when a new contract is signed, this does not allow the verification of diversion because the additional resources could derive from lower consumption in previous periods, which is not verifiable. The fraction of lost income $\phi$ can be interpreted as the cost for hiding (making nonverifiable) the diverted income and for hiding consumption. Again, the intermediary knows that the additional resources come from diversion, but it cannot legally prove it.

The last assumption is limited liability. Agents can renegotiate negative values of net worth and, therefore, $a\left(s_{n}\right) \geq 0$. The agent's problem reads as

$$
V_{t}(s, a)=\max _{c, k, b\left(s^{\prime}\right)}\left\{U(c)+\beta \sum_{s^{\prime}} V_{t+1}\left(s^{\prime}, a\left(s^{\prime}\right)\right) g\left(s, s^{\prime}\right)\right\}
$$


subject to

$$
\begin{aligned}
a & =c+k P_{t}+\sum_{s^{\prime}} b\left(s^{\prime}\right) q\left(s, s^{\prime}\right), \\
a\left(s^{\prime}\right) & =w^{\prime}+z^{\prime} k^{\nu}+k P_{t+1}+b\left(s^{\prime}\right), \\
V_{t}\left(s_{n}, a\left(s_{n}\right)\right) & \geq V_{t}\left(s_{n}, a\left(s_{1}\right)+(1-\phi) \cdot\left[w_{n}-w_{1}+\left(z_{n}-z_{1}\right) k^{\nu}\right]\right), \\
a\left(s_{n}\right) & \geq 0 .
\end{aligned}
$$

Using standard arguments, we can prove that there is a unique solution and the function $V_{t}(s, a)$ is strictly increasing and concave in $a .{ }^{16}$ The strict monotonicity of the value function implies that the incentive-compatibility constraint can be written as

$$
a\left(s_{n}\right) \geq a\left(s_{1}\right)+(1-\phi) \cdot\left[w_{n}-w_{1}+\left(z_{n}-z_{1}\right) k^{\nu}\right]
$$

for all $n=1, \ldots, N$. This is the constraint we imposed on the original problem.

We arrived at this simple formulation of the enforcement constraints because of the particular environment we considered. With an alternative assumption of information asymmetries and persistent shocks, the characterization of the optimal contract becomes more complicated. Because the qualitative properties are similar to the frictions considered here (see, e.g., Fernandes and Phelan 2000), we opted for the simpler route.

\section{Appendix C}

\section{Analytical Proofs}

Proof of Proposition 1

In both economies we have that $R(k, \bar{z})=1+r_{t}$. Because with capital mobility there is a single worldwide interest rate, all agents employ the same input of capital $k=1$. Therefore, the net position in the productive asset is zero. We want to show that the interest rate is smaller than the intertemporal discount rate. Suppose, on the contrary, that $\beta\left(1+r_{t}\right) \geq 1$. Under this condition agents in C1 will have nonnegative consumption growth (see lemma 1) and agents in C2 will have positive consumption growth (see lemma 2). This implies that worldwide consumption growth is positive, which cannot be an equilibrium because aggregate income is constant. Therefore, the equilibrium must satisfy $\beta\left(1+r_{t}\right)<1$. Under this condition, agents in C1 will experience negative consumption growth (see again lemma 1) until the limited liability constraint (4) binds. Therefore, at some point, the net worth becomes zero for all agents. Because in C1 the net holding of productive assets is equal to the domestic endowment of one, the budget constraint becomes $c_{t}+P_{t}+\sum_{w_{t+1}} b\left(w_{t+1}\right) q\left(w_{t}\right.$, $\left.w_{t+1}\right)=0$. This implies $\sum_{w_{t+1}} b\left(w_{t+1}\right) q\left(w_{t}, w_{t+1}\right)<0$; that is, C1 borrows from C2 (the NFA is negative). QED

\footnotetext{
${ }^{16}$ The proof is facilitated by defining the variable $x=k^{\nu}$. After the change of variables $k=x^{1 / \nu}$ is made, it can be easily proved that this is a standard concave problem.
} 
Proof of Proposition 2

Suppose that $\beta(1+r) \geq 1$. Under this condition agents in $\mathrm{C} 1$ will have nonnegative consumption growth and agents in C2 will have strictly positive consumption growth (lemmas 1 and 2 apply also to the case with only investment shocks). This implies that worldwide consumption growth is positive, which cannot be a steady-state equilibrium. Therefore, $\beta\left(1+r_{t}\right)<1$. Under this condition agents in C1 will experience negative consumption growth (see again lemma 1) until the limited liability constraint (4) binds. Therefore, at some point, the net worth becomes zero for all agents. As in proposition 1, this implies that the NFA position of $\mathrm{C} 1$ becomes negative.

To show that $\mathrm{C} 1$ has a positive net position in the productive asset, consider again the first-order conditions (11)-(14). From these conditions we have that $E R_{t}\left(k, z^{\prime}\right)=1+r$ in $\mathrm{C} 1$ and $E R_{t}\left(k, z^{\prime}\right)>1+r$ in C2. The monotonicity of $R_{t}$ with respect to $k$ implies that the productive asset used by agents in C1 is bigger than the productive asset used by agents in C2. Because the supply is the same, C1 must own part of the productive asset of C2.

What remains to be shown is that for $\mathrm{C} 1$ the average return from the foreign productive investment is higher than the cost of its foreign liabilities. Even though the marginal return from the productive asset is equalized to the interest rate, the concavity of the production function implies that the average return is higher than the interest rate. This compensates the managerial capital. QED

\section{Appendix D}

\section{Computational Procedure}

We show first that the economy with contingent claims is equivalent to an economy in which contingent claims are not allowed but agents face a different process for the exogenous shocks. We can then solve the equivalent economy in which the agents' problem is a standard portfolio choice over riskless and risky assets. After showing this, we describe the computational procedures used to solve for the steady-state and transitional equilibria.

\section{A. Equivalent Economy}

Let $\bar{b}_{t}$ be the expected next period value of contingent claims, that is, $\bar{b}_{t}=$ $\sum_{s_{t+1}} b\left(s_{t+1}\right) g\left(s_{t}, s_{t+1}\right)$. Then a contingent claim can be rewritten as $b\left(s_{t+1}\right)=\bar{b}_{t}+$ $x\left(s_{t+1}\right)$, where $\sum_{s_{t+1}} x\left(s_{t+1}\right) g\left(s_{t}, s_{t+1}\right)=0$. The variable $\bar{b}_{t}$ can be interpreted as a noncontingent bond and $x\left(s_{t+1}\right)$ is the pure insurance component of contingent claims. The law of motion for the next period assets becomes

$$
a\left(s_{t+1}\right)=w_{t+1}+\sum_{j=1}^{I}\left(k_{j, t} P_{t+1}^{j}+z_{j, t+1} A_{j, t}^{1-\nu} k_{j, t}^{\nu}\right)+\bar{b}_{t}+x\left(s_{t+1}\right) .
$$


Because agents will choose as much insurance as possible, the incentivecompatibility constraint will be satisfied with equality, that is,

$$
a\left(s_{n}\right)=a\left(s_{1}\right)+(1-\phi) \cdot\left[w_{n}-w_{1}+\sum_{j=1}^{I}\left(z_{j, n}-z_{j, 1}\right) A_{j, t}^{1-\nu} k_{j, t}^{\nu}\right] .
$$

Using the law of motion for $a$, we can write the constraint as

$$
x\left(s_{n}\right)-x\left(s_{1}\right)=-\boldsymbol{\phi} \cdot\left[w_{n}-w_{1}+\sum_{j=1}^{I}\left(z_{j, n}-z_{j, 1}\right) A_{j, t}^{1-\nu} k_{j, t}^{\nu}\right],
$$

which must hold for all $n \in\{2, \ldots, N\}$. The variables $x\left(s_{n}\right)$ must also satisfy the zero-profit condition, that is,

$$
\sum_{n} x\left(s_{n}\right) g\left(s_{t}, s_{n}\right)=0 .
$$

Therefore, we have $N$ conditions and $N$ unknowns. We can then solve for all the $N$ values of $x_{n}$. The solution can be written as

$$
x\left(s_{n}\right)=-\phi \cdot W_{n}\left(s_{t}\right)-\phi \cdot \sum_{j=1}^{I} Z_{j, n}\left(s_{t}\right) \cdot A_{j, t}^{1-\nu} k_{j, t}^{v},
$$

where $W_{n}\left(s_{t}\right)$ and $Z_{j, n}\left(s_{t}\right)$ are exogenous variables defined as

$$
\begin{aligned}
& W_{n}\left(s_{t}\right)=w_{n}-\sum_{l} g\left(s_{t}, s_{l}\right) w_{l}, \\
& Z_{j, n}\left(s_{t}\right)=z_{j, n}-\sum_{l} g\left(s_{t}, s_{l}\right) z_{j, l} .
\end{aligned}
$$

These variables depend on the current shocks because they affect the probability distribution for the next period shocks.

Define the following variables:

$$
\begin{aligned}
& \tilde{w}_{n}\left(s_{t}\right)=w_{n}-\phi \cdot W_{n}\left(s_{t}\right), \\
& \tilde{z}_{j, n}\left(s_{t}\right)=z_{j, n}-\phi \cdot Z_{j, n}\left(s_{t}\right) .
\end{aligned}
$$

These are transformations of the shocks. Using the transformed shocks, we can write the law of motion for next period assets as

$$
a\left(s_{n}\right)=\tilde{w}_{n}\left(s_{t}\right)+\sum_{j}^{I}\left[k_{j, t} P_{t+1}^{j}+\tilde{z}_{j, n}\left(s_{t}\right) \cdot A_{j, t}^{1-\nu} k_{j, t}^{\nu}\right]+\bar{b}_{t} .
$$

Therefore, when we use the transformed shocks $\tilde{w}_{n}\left(s_{t}\right)$ and $\tilde{z}_{j, n}\left(s_{t}\right)$, it is as if agents choose only noncontingent claims. Then the problem becomes a standard portfolio choice between risky assets, $k_{j, t}$, and a riskless asset, $\bar{b}_{t}$. Differences in financial development are captured by differences in the stochastic properties of the transformed shock. So, for example, if $\phi=0$, we go back to the original shock because contingent claims are not feasible. If $\phi=1$ and shocks are i.i.d., the transformed shock becomes a constant. We are in the case of full insurance. Intermediate values of $\phi$ allow only for partial insurance. In the computation we will solve the portfolio choice in the transformed model. 
B. Steady-State Equilibrium

1. Choose a grid for asset holdings $a$.

2. Guess the steady-state interest rate, $r$, and the prices $\left\{P^{j}\right\}_{j=1}^{I}$.

3. Using the first-order conditions, solve for the optimal portfolio choices at each grid point of $a$ and for each $s$ by iterating on the policy rules. The solutions at each grid point are joined with piecewise linear functions.

4. Find the steady-state distribution of agents using the decision rules and compute the clearing conditions for the risky and riskless assets.

5. Update the guesses for the interest rate and the prices of the productive assets (step 2) until the market-clearing conditions are satisfied.

C. Transitional Equilibrium

1. Solve for the initial and final steady states (autarky and mobility).

2. Choose the number of transition periods $T$. This number should be sufficiently large to allow the economy to reach, approximately, the new steady state in $T$ periods.

3. Guess transition sequences for the interest rates, $\left\{r_{t}\right\}_{t=1}^{T}$, and for the price of the productive assets, $\left\{\left\{P_{t}^{j}\right\}_{j=1}^{I}\right\}_{t=1}^{T}$. The final prices $\left\{P_{T+1}^{j}\right\}_{j=1}^{I}$ are set to the steady-state values with mobility found in step 1 .

4. Using the first-order conditions, solve for the optimal portfolio choices backward starting from $T$. This provides the sequence of optimal decision rules at $t=1,2, \ldots, T$.

5. Using the optimal decision rules, find the sequence of distributions and compute the market-clearing conditions at time $t=1,2, \ldots, T$.

6. Update the guess for the sequences of the interest rates and the prices of the productive assets (step 3) until the market-clearing conditions are satisfied for each $t=1,2, \ldots, T$.

\section{References}

Abiad, Abul, Enrica Detragiache, and Thierry Tressel. 2008. "A New Database of Financial Reforms.” Working Paper no. 08/266 (December), Internat. Monetary Fund, Washington, DC.

Aiyagari, S. Rao. 1994. "Uninsured Idiosyncratic Risk and Aggregate Saving." Q.J.E. 109 (3): 659-84.

Angeletos, George-Marios. 2007. "Uninsured Idiosyncratic Investment Risk and Aggregate Saving." Rev. Econ. Dynamics 10 (1): 1-30.

Attanasio, Orazio, Sagiri Kitao, and Giovanni L. Violante. 2006. "Quantifying the Effects of the Demographic Transition in Developing Economies." $B . E$. J. Macroeconomics (Advances) 6 (1): art. 2. http://www.bepress.com/bejm/ advances.

Backus, David, Espen Henriksen, Frederic Lambert, and Chris Telmer. 2005. 
"Current Account Fact and Fiction." Manuscript, Stern School Bus., New York Univ.

Bailey, Warren. 1994. "Risk and Return on China's New Stock Markets: Some Preliminary Evidence." Pacific-Basin Finance J. 2 (2-3): 243-60.

Bernanke, Ben S. 2005. "The Global Saving Glut and the U.S. Current Account Deficit." Speech at the Sandridge Lecture, Virginia Assoc. Economists, Richmond, VA, March 10.

Bewley, Truman F. 1986. "Stationary Monetary Equilibrium with a Continuum of Independent Fluctuating Consumers." In Contributions to Mathematical Economics in Honor of Gerard Debreu, edited by Werner Hildenbrand and Andreu Mas-Colell. Amsterdam: North-Holland.

Blanchard, Olivier, Francesco Giavazzi, and Filipa Sa. 2005. "The U.S. Current Account and the Dollar." Working Paper no. 11137 (February), NBER, Cambridge, MA.

Caballero, Ricardo J., Emmanuel Farhi, and Pierre-Olivier Gourinchas. 2008. "An Equilibrium Model of 'Global Imbalances' and Low Interest Rates." A.E.R. 98 (1): 358-93.

Carroll, Christopher D. 1997. "Buffer-Stock Saving and the Life Cycle/Permanent Income Hypothesis." Q.J.E. 112 (1): 1-56.

Carroll, Christopher D., and Olivier Jeanne. 2008. "A Tractable Model of Precautionary Reserves or Net Foreign Assets.” Manuscript, Johns Hopkins Univ.

Castro, Rui, Gian Luca Clementi, and Glenn MacDonald. 2004. "Investor Protection, Optimal Incentives, and Economic Growth.” Q.J.E. 119 (3): 1131-75.

Cavallo, Michele, and Cedric Tille. 2006. "Could Capital Gains Smooth a Current Account Rebalancing?” Staff Report no. 237, Fed. Reserve Bank New York.

Chakraborty, Suparna, and Robert Deckle. 2007. "Global Imbalances, Productivity Differentials and Financial Integration.” Working Paper no. 07.14 (October), Inst. Econ. Policy Res., Los Angeles.

Chinn, Menzie D., and Hiro Ito. 2005. "What Matters for Financial Development? Capital Controls, Institutions, and Interactions." Working Paper no. 11370 (May), NBER, Cambridge, MA.

Croke, Hilary, Steven B. Kamin, and Sylvain Leduc. 2005. "Financial Market Developments and Economic Activity during Current Account Adjustments in Industrial Economies.” International Finance Discussion Papers no. 827 (February), Bd. Governors, Fed. Reserve System, Washington, DC.

Curcuru, Stephanie E., Tomas Dvorak, and Francis E. Warnock. 2008. "CrossBorder Returns Differentials.” Q.J.E. 123 (4): 1495-1530.

Deckle, Robert, Jonathan Eaton, and Samuel Kortum. 2007. "Unbalanced Trade." Working Paper no. 13035 (April), NBER, Cambridge, MA.

Durdu, Ceyhun Bora, Enrique G. Mendoza, and Marco E. Terrones. 2009. "Precautionary Demand for Foreign Assets in Sudden Stop Economies: An Assessment of the New Merchantilism." J. Development Econ. 89 (2): 194-209.

Engel, Charles, and John H. Rogers. 2006. "The U.S. Current Account Deficit and the Expected Share of World Output." International Finance Discussion Papers no. 856 (April), Bd. Governors, Fed. Reserve System, Washington, DC.

Faruqee, Hamid, Douglas Laxton, and Paolo A. Pesenti. 2007. "Smooth Landing or Crash? Model-Based Scenarios of Global Current Account Rebalancing." In G7 Current Account Imbalances: Sustainability and Adjustment, edited by Richard H. Clarida, 377-451. Chicago: Univ. Chicago Press.

Fernandes, Ana, and Christopher Phelan. 2000. "A Recursive Formulation for Repeated Agency with History Dependence.” J. Econ. Theory 91 (2): 223-47.

Fogli, Alessandra, and Fabrizio Perri. 2006. "The Great Moderation and the US 
External Imbalance.” Working Paper no. 12708 (November), NBER, Cambridge, MA.

Ghironi, Fabio, Jaewoo Lee, and Alessandro Rebucci. 2007. "The Valuation Channel of External Adjustment." Working Paper no. 12937 (February), NBER, Cambridge, MA.

Gourinchas, Pierre Olivier, and Olivier Jeanne. 2007. "Capital Flows to Developing Countries: The Allocation Puzzle.” Working Paper no. 13602, NBER, Cambridge, MA.

Gourinchas, Pierre Olivier, and Helen Rey. 2007. "From World Banker to World Venture Capitalist: US External Adjustment and the Exorbitant Privilege." In G7 Current Account Imbalances: Sustainability and Adjustment, edited by Richard H. Clarida, 11-66. Chicago: Univ. Chicago Press.

Hausmann, Ricardo, and Federico Sturzenegger. 2005. "U.S. and Global Imbalances: Can Dark Matter Prevent a Big Bang?” Working Paper no. 124 (November), Center Internat. Development, Harvard Univ.

Henriksen, Espen R. 2005. "A Demographic Explanation of U.S. and Japanese Current Account Behavior." Manuscript, Univ. Oslo.

Huggett, Mark. 1993. "The Risk-Free Rate in Heterogeneous-Agent IncompleteInsurance Economies." J. Econ. Dynamics and Control 17 (5/6): 953-70.

Hunt, Benjamin, and Alessandro Rebucci. 2005. "The U.S. Dollar and the Trade Deficit: What Accounts for the Late 1990s?” Internat. Finance 8 (3): 399-434.

IMF (International Monetary Fund). 2005. "Economic Prospects and Policy Issues." In World Economic Outlook: Global and External Imbalances, chap. 1. Washington, DC: IMF.

. 2006. "How Do Financial Systems Affect Economic Cycles?" In World Economic Outlook, September 2006: Financial Systems and Economic Cycles, chap. 4. Washington, DC: IMF.

Khan, Azizur R., and Carl Riskin. 2001. Inequality and Poverty in China in the Age of Globalization. New York: Oxford Univ. Press.

Kim, Soyoung, Sunghyun H. Kim, and Yunjong Wang. 2006. "Financial Integration and Consumption Risk Sharing in East Asia." Japan and World Econ. 18 (2): 143-57.

Krugman, Paul. 2006. "Will There Be a Dollar Crisis?" Manuscript, Princeton Univ.

Lane, Philip R., and Gian Maria Milesi-Ferretti. 2007. "A Global Perspective on External Position.” In G7 Current Account Imbalances: Sustainability and Adjustment, edited by Richard H. Clarida, 67-98. Chicago: Univ. Chicago Press.

McGrattan, Ellen R., and Edward C. Prescott. 2008. "Technology Capital and the U.S. Current Account.” Staff Report no. 406 (April), Fed. Reserve Bank Minneapolis.

Mendoza, Enrique, Vincenzo Quadrini, and José-Víctor Ríos-Rull. 2008. "On the Welfare Implications of Financial Globalization without Financial Development." In International Seminar on Macroeconomics 2007, edited by Richard H. Clarida and Francesco Giavazzi. Chicago: Univ. Chicago Press (for NBER).

Naughton, Barry. 2007. The Chinese Economy: Transitions and Growth. Cambridge, MA: MIT Press.

Obstfeld, Maurice, and Kenneth Rogoff. 2004. "The Unsustainable U.S. Current Account Position Revisited.” Working Paper no. 10869 (November), NBER, Cambridge, MA.

Prades, Elvira, and Katrin Rabitsch. 2007. "Capital Liberalization and the U.S. External Imbalance.” Manuscript, European Univ. Inst., Florence.

Rotemberg, Julio, and Michael Woodford. 1995. "Dynamic General Equilibrium 
Models with Imperfectly Competitive Product Markets.” In Frontiers of Business Cycle Research, edited by Thomas F. Cooley, chap. 9. Princeton, NJ: Princeton Univ. Press.

Roubini, Nouriel, and Brad Setser. 2005. "Will the Bretton Woods 2 Regime Unravel Soon? The Risk of a Hard Landing in 2005-2006." Manuscript, New York Univ. and Oxford Univ.

Storesletten, Kjetil, Chris Telmer, and Amir Yaron. 2004. "Cyclical Dynamics in Idiosyncratic Labor Market Risk.” J.P.E. 112 (3): 695-717.

Summers, Lawrence H. 2004. "The United States and the Global Adjustment Process." Speech at the third annual Stavros S. Niarchos Lecture, Inst. Internat. Econ., Washington, DC, March 23.

Willen, Paul S. 2004. "Incomplete Markets and Trade." Working Paper no. 048, Fed. Reserve Bank Boston.

$\mathrm{Xu}$, Xinpeng. 2008. "Consumption Risk-Sharing in China." Economica 75:32641. 